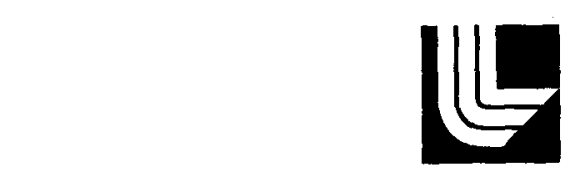

LAWRENCE LIVERMORE LABORATORY

University of Caltornia/Livermore; California/94550

UCRL-52656

\title{
SURVEY OF GAS QUALITY RESULTS FROM THREE GAS-WELL-STIMULATION EXPERIMENTS BY NUCLEAR EXPLOSIONS
}

Howard A. Tewes

MS. Date: January 23, 1979

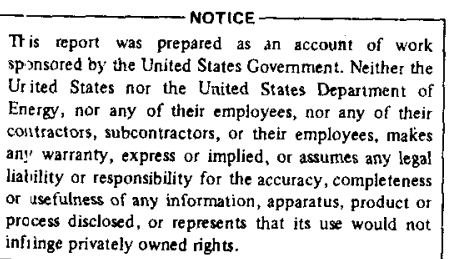

This document is PUBLICLY RELEASABLE Lasu \&? 2clllém Authofizing Official 


\section{DISCLAIMER}

This report was prepared as an account of work sponsored by an agency of the United States Government. Neither the United States Government nor any agency Thereof, nor any of their employees, makes any warranty, express or implied, or assumes any legal liability or responsibility for the accuracy, completeness, or usefulness of any information, apparatus, product, or process disclosed, or represents that its use would not infringe privately owned rights. Reference herein to any specific commercial product, process, or service by trade name, trademark, manufacturer, or otherwise does not necessarily constitute or imply its endorsement, recommendation, or favoring by the United States Government or any agency thereof. The views and opinions of authors expressed herein do not necessarily state or reflect those of the United States Government or any agency thereof. 


\section{DISCLAIMER}

Portions of this document may be illegible in electronic image products. Images are produced from the best available original document. 


\section{CONTENTS}

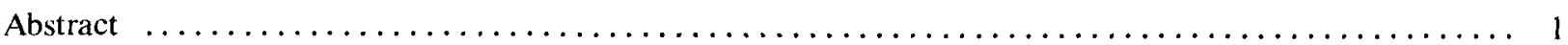

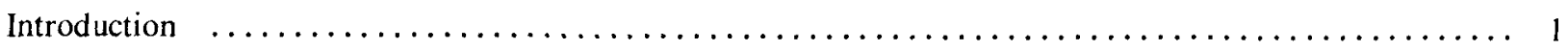

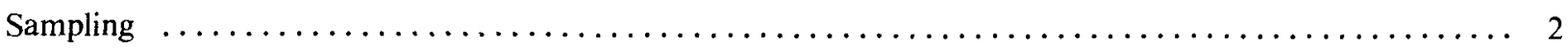

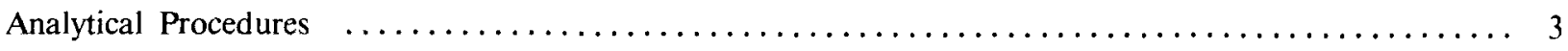

Results and Discussion, Observed Product Gas Composition $\ldots \ldots \ldots \ldots \ldots \ldots \ldots$

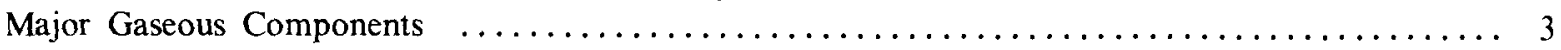

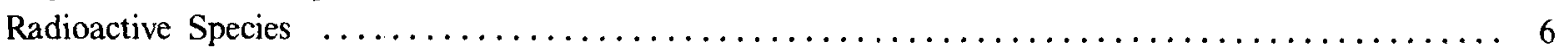

Concentration Changes in Major Gaseous Components $\ldots \ldots \ldots \ldots \ldots \ldots \ldots \ldots \ldots \ldots \ldots$

Total Amounts of Product Gases

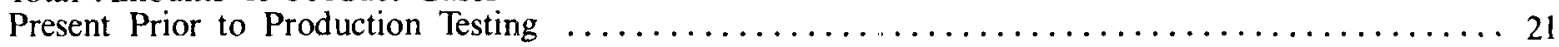

Potential Radiation Doses to Man Resulting from Widespread

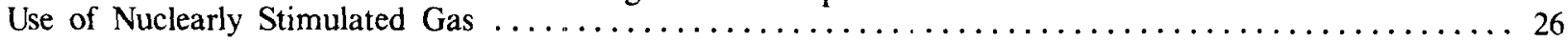

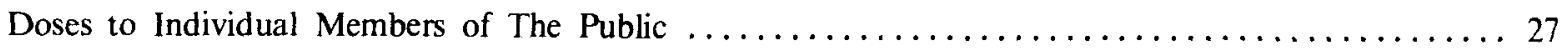

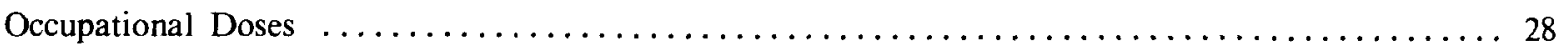

Population Doses from Full-Field Development $\ldots \ldots \ldots \ldots \ldots \ldots \ldots \ldots \ldots \ldots \ldots$

Regulatory Issues in the Use of Nuclearly Stimulated Natural Gas $\ldots \ldots \ldots \ldots \ldots \ldots$

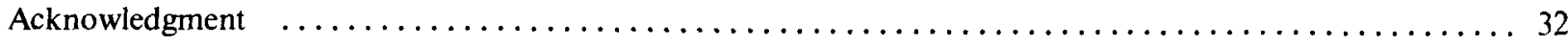

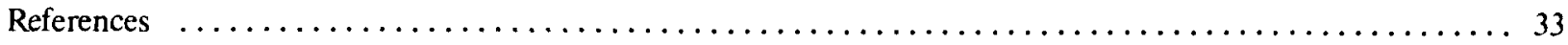




\title{
SURVEY OF GAS QUALITY RESULTS FROM THREE GAS-WELL-STIMULATION EXPERIMENTS BY NUCLEAR EXPLOSIONS
}

\begin{abstract}
Gas quality results obtained at LLL on samples taken from the three nuclear gas-wellstimulation experiments (Gasbuggy, Rulison, Rio Blanco) are used to illustrate the differences and similarities of the three projects. All of the gas analysis data shown here have been previously published in LLL reports, but heretofore, intercomparisons have been difficult because of the different formats used in the various publications. Also, the data from the three experiments have not previously been manipulated in the same way so that postshot conditions in the three cavity and chimney systems could be compared. As the pressure and temperature increase in the cavity and chimney system (as they do with increasing depth of burial) the amount of water produced with the chimney gas increases markedly. Differences in late-time additions of $\mathrm{CO}_{2}$ to the chimney gas were also observed. Previously reported radiological safety studies of the potential effects from the use of nuclearly stimulated gas are discussed, and the required steps that could lead to the possible sale of nuclearly stimulated gas to the general public are listed.
\end{abstract}

\section{INTRODUCTION}

Three experiments to investigate the feasibility of stimulating low permeability natural gas formations by nuclear explosions were carried out under the auspices of the Plowshare Program of the U. S. Atomic Energy Commission (now the Department of Energy). These are characterized in Table 1.

This report has been prepared to summarize in a consistent format the basic gas composition data obtained from LLL analyses of gas samples from these three experiments, and also to provide an overview of the various predictions of the radiological consequences from the widespread use of nuclearly stimulated gas.

Brief summaries of well reentries and gas releases from the three projects are presented as follows:

Gasbuggy. Reentry drilling to the chimney top through the emplacement casing was begun on
December 12, 1967. On January 17, 1968 after completion of reentry drilling, the well was allowed to flow about $8500 \mathrm{~m}^{3}$ (300 MSCF), ${ }^{*}$ providing the first opportunity to take significant gas samples at the wellhead. Samples were also collected during production tests run during the intervals June 28-July 10, 1968, July 11-July 14, 1969, and October 28-November 14 , 1969. Some $8.1 \times 10^{6} \mathrm{~m}^{3}$ (285 MMSCF) $\dagger$ of gas were producad (see Ref. 1 for details).

Rulison. Reentry drilling operations were initiated in April 1970; the fractured zone near the top of the chimney was penetrated in July 1970, and the well was completed for production testing. Samples were taken during short periods of calibration flaring in August

"MSCF $=$ thousand standard cubic feet.

${ }^{\dagger} \mathrm{MMSCF}=$ million standard cubic feet.

TABLE 1. U. S. gas-well-stimulation experiments by nuclear explosions.

\begin{tabular}{lccccccc}
\hline Name & Date & $\begin{array}{c}\text { Time } \\
(\mathbf{G M T})\end{array}$ & $\begin{array}{c}\text { Nominal } \\
\text { yield (kt) }\end{array}$ & Coordinates & Location & Near & $\begin{array}{c}\text { Depth of burst } \\
\text { (m) }\end{array}$ \\
\hline Gasbuggy & $12 / 10 / 67$ & 1930 & 29 & $36.68^{\circ} \mathrm{N}-107.21^{\circ} \mathrm{W}$ & Farmington, N. Mex. & 1293 \\
Rulison & $9 / 10 / 69$ & 2100 & 40 & $39.41^{\circ} \mathrm{N}-107.95^{\circ} \mathrm{W}$ & Rulison, Colo. & 2573 \\
Rio Blanco & $5 / 17 / 73$ & 1600 & $3 \times 30$ & $39.79^{\circ} \mathrm{N}-108.37^{\circ} \mathrm{W}$ & Rifle, Colo. & 1780 \\
& & & & & & 1899 \\
& & & & & & 2039 \\
\hline
\end{tabular}


and October, 1970. Additional samples were obtained during three production tests (October 26 through November 3, 1970, December 1 through December 20, 1970, and February 3, 1971 through April 23, 1971). Total flow of gas during the production periods was $6.0 \times 10^{6} \mathrm{~m}^{3}$ (212 MMSCF). For additional details, see Ref. 2 .

Rio Blanco (Top chimney). Reentry drilling into the chimney region above the detonation point of the upper explosive was started September 23, 1973. The hole was completed to a depth of $1732 \mathrm{~m} \mathrm{(48} \mathrm{m}$ above the top explosive) on October 11, 1973. Because connection with the top chimney was poor, the hole was reentered again and drilled to a total depth of $1744 \mathrm{~m}$; this depth was reached on October 19, 1973. A few preliminary gas samples were taken during the casing bleeddown prior to the second reentry. Other samples were taken during production tests on October 25, 1973, November 15 through November 21, 1973, and
January 28 through February 15, 1974. A total of $2.8 \times 10^{6} \mathrm{~m}^{3}$ (98 MMSCF) of dry gas was flared during the course of the production testing; see Ref 3 for a more detailed discussion of the production testing.

Rio Blanco (Bottom chimney). Drilling of the alternate Rio Blanco reentry well was begun in June, 1974; the hole was originally directed toward the middle cavity and chimney system, but slant drilling difficulties required that the hole be redirected toward the bottom chimney. After the completion of the well, the first gas returns were obtained on October 22, 1974. A calibration test was conducted on November 2, 1974, and a production test was carried out between December 10 and December 16, 1974. Gas samples were taken during the calibration and production tests; a total of $7.5 \times 10^{5} \mathrm{~m}^{3}$ (27 MMSCF) of dry gas was flared during the two testing periods (see Ref. 4 for details).

\section{SAMPLING}

On all three experiments, gas samples were taken at regular intervals during production testing; also, in most cases, a number of samples were taken before the start of production testing in order that initial concentrations of radioactive and nonradioactive species would be well-established. The sampling history for each experiment will not be given here, but references will be given to publications in which such histories are shown in detail.

Gasbuggy. After the start of production testing, all gas samples were obtained using evacuated sample bottles connected to existing blowdown equipment at the wellhead. All samples were obtained during the course of gas releases sufficient to ensure that the well pipe had been thoroughly flushed. Sampling bottles with capacities of 0.8 and 8 litres were used. Prior to the start of production testing, a number of samples were also obtained using small evacuated sampling bottles that were lowered to a depth of about $1165 \mathrm{~m}$, opened, and allowed to equilibrate. Reference 1 contains a complete listing of samples collected by LLL.

Rulison. Because LLL was not the lead laboratory for the Rulison experiment, routine gas sampling was not carried out by LLL. However, a number of gas samples were collected by LLL during production testing to obtain supplemental and confirmatory data. All samples were collected downstream of the separator* in 0.5-litre evacuated stainless steel sample bottles.
Reference 2 gives additional detail on the individual samples that were taken.

Rio Blanco (Top chimney). Gas samples were collected directly from the line connecting the wellhead with the flare stack; in the period through the November 1973 production test the sampling location was between the wellhead and the separator. Due to the large amounts of water being produced with the gas, the collection of satisfactory gas samples from this location in the line proved to be difficult. Consequently, after the conclusion of the November 1973 production test, the gas sampling location was moved downstream from the separator. Early samples were collected in 0.115-litre single-valved high-pressure cylinders, which were flushed with the gas several times to remove residual air from the cylinder. Later samples were collected in commercial 0.5 -litre double-valved vessels, which also were flushed several times with gas to prevent sample contamination with air. Reference 3 gives more detail on sampling procedures used in this experiment.

Rio Blanco (Bottom chimney). Sampling was carried out using a configuration essentially identical to that employed during the 1974 production test of the top Rio Blanco chimney; samples were collected in the 0.5-litre double-valved vessels (see Ref. 4).

\footnotetext{
*The separator is designed to remove most of the water from the gas stream; hence, the gas samples were essentially dry.
} 


\section{ANALYTICAL PROCEDURES}

Somewhat similar procedures were used to analyze gas samples from the three gas stimulation experiments. For specific details of analyses and data treatment, see Refs. 1 through 4.

Chemical Analysis. All gas samples were analyzed by means of mass spectroscopy; compositions of the gas samples were calculated assuming that all of the oxygen detected in the samples could be attributed to air contamination. Corrections for $\mathrm{N}_{2}$ and $\mathrm{Ar}$ were determined accordingly.

Analysis for Radioactive Components. Approximate ${ }^{85} \mathrm{Kr}$ radioactivity content of gas samples was generally determined by thin-window beta counting of the untreated samples. The samples were then separated and the gaseous components were purified by means of elution chromatography; carriers, such as stable $\mathrm{Kr}$ and $\mathrm{Ar}$ gas, were added to aid in the recovery of trace components. Next, ${ }^{85} \mathrm{Kr},{ }^{37} \mathrm{Ar}$, and ${ }^{39} \mathrm{Ar}$ were determined using thin-window beta counting on purified samples; compounds containing ${ }^{3} \mathrm{H}$ or ${ }^{14} \mathrm{C}$ were assayed by internal proportional counting of duplicate or quadruplicate fractions of dry gas. In many cases, it was necessary to use special techniques to gain sensitivity in the determination of noble gas radionuclides (see Refs. 3 and 4 for specifics).

\section{RESULTS AND DISCUSSION, OBSERVED PRODUCT GAS COMPOSITION}

\section{MAJOR GASEOUS COMPONENTS}

Prior to the execution of the Gasbuggy experiment, predictions of gas quality were made. ${ }^{5}$ The only noncondensable gas contaminant expected to be present in significant quantity was $\mathrm{CO}_{2}$, which would be produced by the thermal decomposition of carbonate minerals present in the detonation environs. This conclusion was also based on observations made on nuclear detonations at the Nevada Test Site. Of course, some water vapor was also expected to be present, and presumably would be produced with the gas. Actual results from the three U. S. gas stimulation experiments are briefly presented as follows:

Gasbuggy. Subsequent to the nuclear stimulation detonation, the gas produced from the Gasbuggy well was found to be markedly different in composition, not only from the gas produced from the same areas before the explosions took place, but also from the composition predicted in the chimney gas. Figure 1 shows how the gas from the Gasbuggy experiment changed in composition as a function of the total amount* of dry gas removed. ${ }^{1}$ The composition of the gas in the well before the nuclear explosion is shown by the horizontal dashed lines; there was no detectable amount of $\mathrm{H}_{2}$ in this gas and only a trace of $\mathrm{CO}_{2}{ }^{6}$ Note that the composition of the gas approached the

*Unless otherwise labelled, all gas flow rates and total production figures used in this section are referenced to normal temperature and pressure $\left(16^{\circ} \mathrm{C}\right.$ and $\left.0.1 \mathrm{MPa}\right)$. predetonation values as more gas was produced from the well, as would be expected if formation gas were replacing the gas being removed from the chimney.

Not shown in Fig. 1 is the $\mathrm{CO}$, which was present in the Gasbuggy gas shortly after the nuclear explosion took place, because this compound had essentially

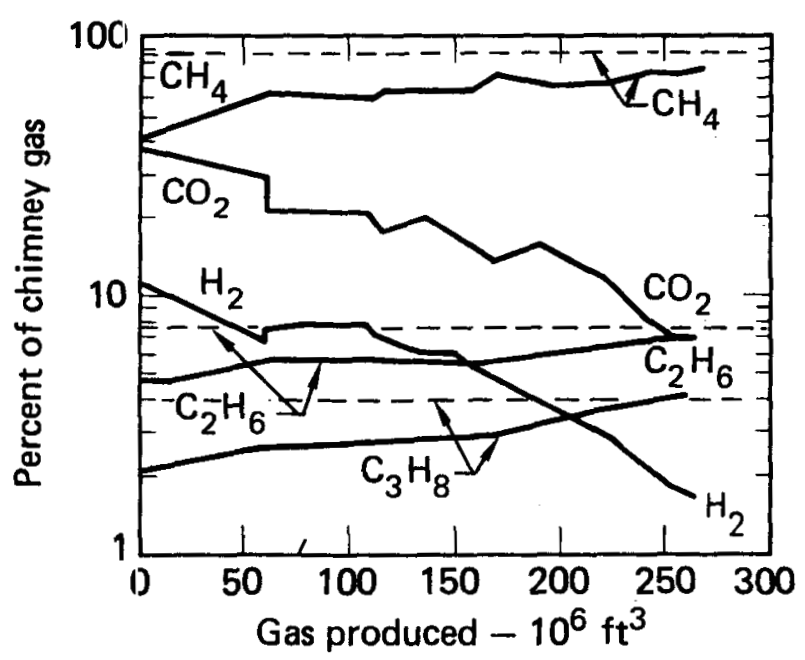

FIG . 1. Composition of gas removed from Gasbuggy chimney as a function of total gas volume removed (taken from Ref. 7-added dashed lines give pre-explosion concentrations of $\mathrm{CH}_{4}, \mathrm{C}_{2} \mathrm{H}_{6}$, and $\mathrm{C}_{3} \mathrm{H}_{8}$; bireak in solid curves represents period of time when no gas was withdrawn). 
disappeared before $1 \times 10^{6} \mathrm{~m}^{3}$ of dry gas had been produced. The concentration of $\mathrm{CO}$ dropped with time during the initial shut-in period of the well, as can be seen from Fig. $2{ }^{7}$

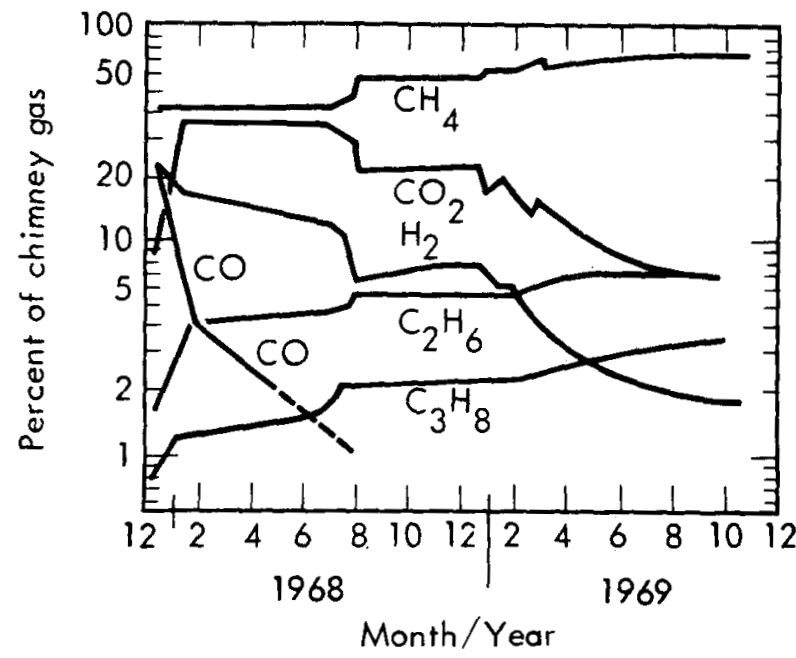

FIG. 2. Composition of gas taken from Gasbuggy well as a function of time (taken from Ref. 7).

Still another component of the Gasbuggy gas as produced was water. It was predicted that the amount of water produced with the gas would be dependent on the downhole partial pressure of water vapor, which in turn would depend on the downhole temperature. As the gas being produced was cooled on its way to the surface, water would be condensed out and entrained in the flowing gas. Actual Gasbuggy water production will be discussed below.

Rulison. Figure 3 presents the chemical composition of Rulison gas as a function of the amount of dry gas produced. ${ }^{2}$ As in the case of Gasbuggy, $\mathrm{CO}_{2}$ and $\mathrm{H}_{2}$ were present in the post-detonation gas, whereas these species were essentially absent in the formation gas. As production testing continued and cavity gas was replaced by formation gas, the composition of the produced gas approached that of the formation gas. However, while the fractional amount of $\mathrm{H}_{2}$ in the gas continued to decline as the total gas production increased, the behavior of $\mathrm{CO}_{2}$ began to diverge from that of the $\mathrm{H}_{2}$, with the mole fraction of $\mathrm{CO}_{2}$ in the gas actually increasing slightly after a total production of $10^{7} \mathrm{~m}^{3}$ of gas.

Because no samples of chimney gas became available at relatively early times following the Rulison explosion (the first samples were obtained over $101 / 2$ months post-detonation), no evidence of the possible formation of $\mathrm{CO}$ was obtained.

Production of water during the course of the Rulison production tests is indicated in Fig. 4. The increasing amount of water associated with a unit volume of dry gas is the result of a sustained partial pressure of water vapor in the cavity (since the downhole temperature remained relatively constant during production testing), coupled with a decreasing pressure of dry gas. ${ }^{8}$

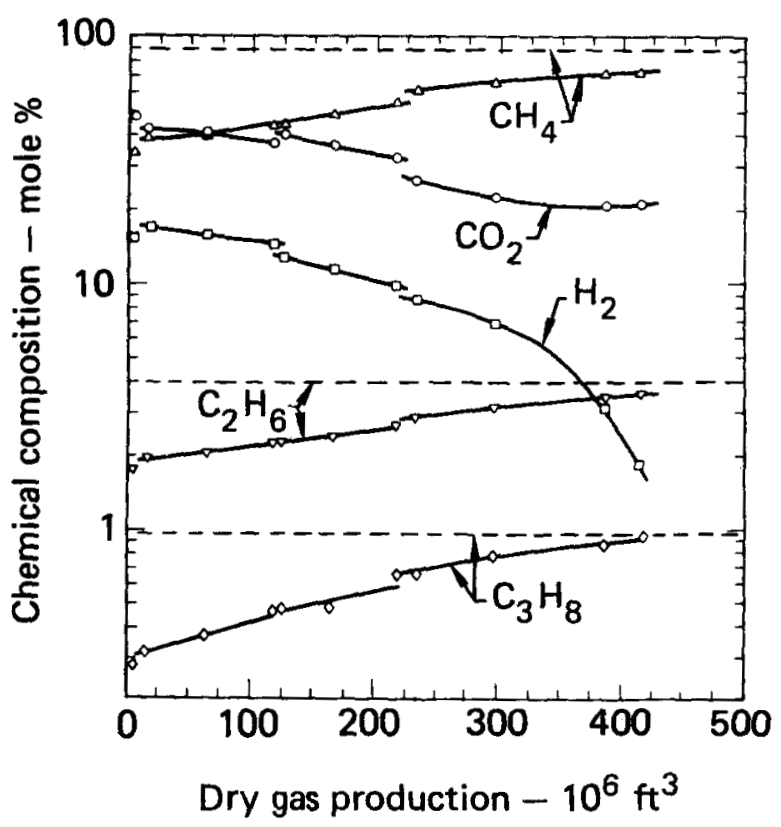

FIG. 3. Chemical composition of gas produced at Project Rulison plotted as a function of dry gas production; data points at $5 \times 10^{6} \mathrm{~m}^{3}$ are average of five samples collected during calibration flaring (taken from Ref. 2-added dashed lines give preexplosion concentrations of $\mathrm{CH}_{4}, \mathrm{C}_{2} \mathrm{H}_{6}$, and $\mathrm{C}_{3} \mathrm{H}_{8}$; break in solid curves represents period of time when no gas was withdrawn).

Rio Blanco. The chemical composition of the gas produced from the Rio Blanco well is shown in Fig. 5 for the top chimney and in Fig. 6 for the bottom chimney. ${ }^{3,4,9}$ The expected explosion-produced $\mathrm{CO}_{2}$ and $\mathrm{H}_{2}$ were present in the gas produced from both cavities, with the initial compositions of the dry gas produced from the two cavities being quite similar. From the production test data obtained for the top cavity, it can be seen that after a total of about $25 \times 10^{6} \mathrm{~m}^{3}$ of dry gas had been flared, the fractional amount of $\mathrm{CO}_{2}$ in the gas began to increase in much the same way as was observed in the Rulison experiment. However, in Rio Blanco, it appears that during the course of production testing, the $\mathrm{H}_{2}$ began to behave like the $\mathrm{CO}_{2}$; i.e., the fractional amount of $\mathrm{H}_{2}$ in the gas no longer changed significantly as more gas was produced. This behavior could not be studied in 


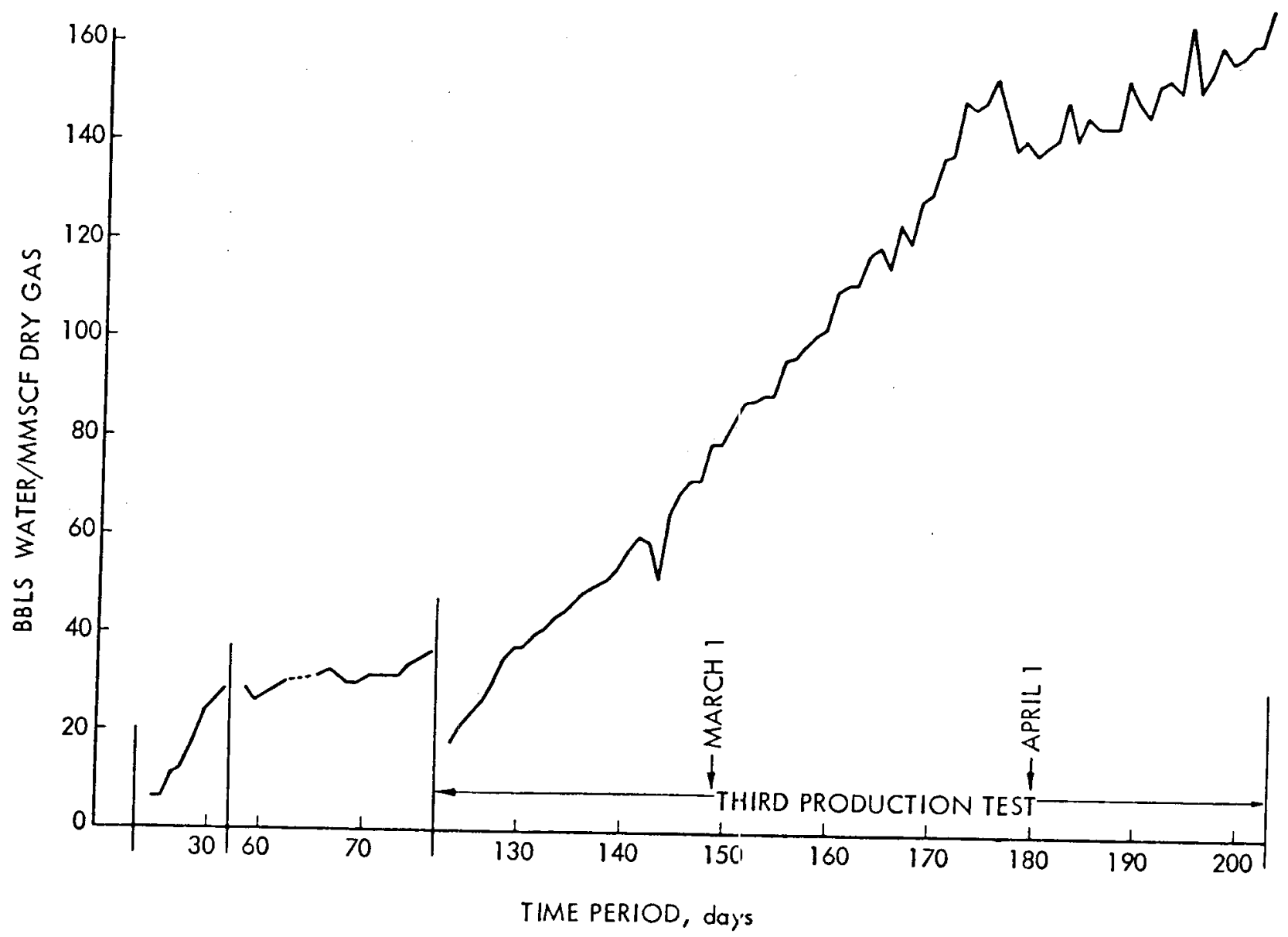

FIG. 4. Daily water production: Rulison (taken from Ref. 8).

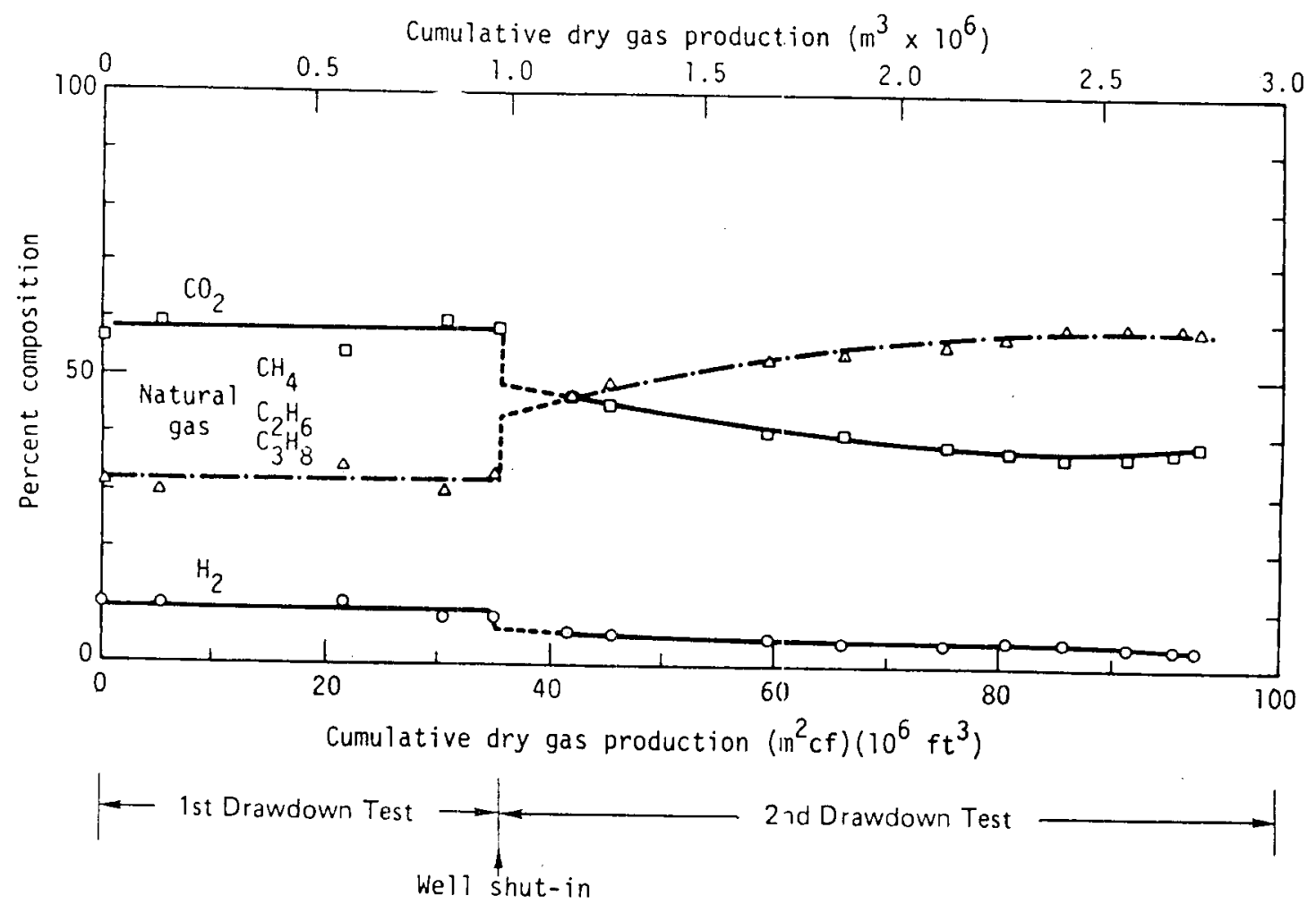

FIG. 5. Gas composition, Rio Blanco top chimney (taken from Ref. 9). 


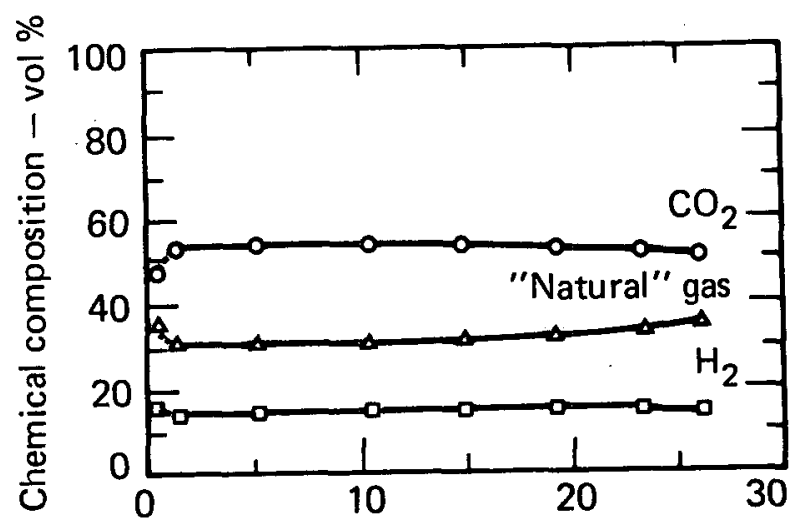

Cumulative dry gas production - MMSCF

FIG. 6. Chemical composition vs production, RB-AR-02 (Rio Blanco bottom chimney) - taken from Ref. 4.

the case of gas production from the lower Rio Blanco chimney, because only about $0.7 \times 10^{6} \mathrm{~m}^{3}$ of dry gas was released during the course of production testing.

Again, as with the Rulison experiment, gas samples from Rio Blanco were unavailable at early times following the detonation because reentry was not accomplished until about 5 months after the explosion. Hence, it was not possible to determine whether or not CO had been formed by the detonation.

The data presented in Fig. 7 on water production from the top Rio Blanco chimney and cavity shows that the amount of water produced per unit volume of dry gas increased rapidly as a function of the total gas produced; as in the case of Rulison, this was to be expected if the total bottom hole pressure dropped significantly while the temperature (and hence the partial pressure of water vapor) remained essentially constant.

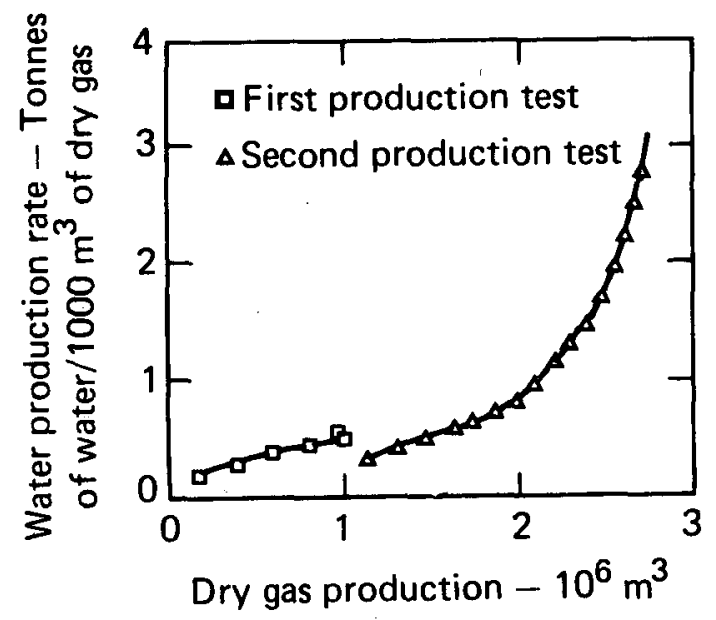

FIG. 7. Rate of water production from Rio Blanco upper chimney.
Summary. The initial concentrations (volume fractions) of the major chemical constituents present initially (before production testing) in the chimneys and cavities of the three gas stimulation experiments are shown in Table 2.

TABLE 2. Initial composition of dry gas present in nuclearly-stimulated gas wells.

\begin{tabular}{ccccc} 
& \multicolumn{3}{c}{ Composition (volume fraction) } \\
\cline { 2 - 5 } & & & \multicolumn{2}{c}{ Rio Blanco } \\
\cline { 3 - 5 } Compound & Gasbuggy & Rulison & $\begin{array}{c}\text { Top } \\
\text { chimney }\end{array}$ & $\begin{array}{c}\text { Bottom } \\
\text { chimney }\end{array}$ \\
\hline $\mathrm{CO}_{2}$ & 0.355 & 0.484 & 0.600 & 0.521 \\
$\mathrm{H}_{2}$ & 0.158 & 0.157 & 0.102 & 0.149 \\
$\mathrm{CH}_{4}$ & 0.389 & 0.328 & 0.284 & 0.297 \\
$\mathrm{C}_{2} \mathrm{H}_{6}$ & 0.039 & 0.017 & 0.006 & 0.020 \\
$\mathrm{C}_{3} \mathrm{H}_{8}$ & 0.011 & 0.003 & $<0.001$ & 0.003 \\
\hline
\end{tabular}

As is discussed in a following section, the amounts of $\mathrm{CO}_{2}$ and $\mathrm{H}_{2}$ in the product gas are critically dependent on both the composition of the rock surrounding the nuclear explosive and the depth of the detonation.

\section{RADIOACTIVE SPECIES*}

In planning for the Gasbuggy experiment, only three gaseous radioactive species were treated in any detail: ${ }^{85} \mathrm{Kr}$, ${ }^{131} \mathrm{I}$, and tritium. ${ }^{10}$ Gaseous radionuclides with shorter half-lives were not considered, because either they would be essentially gone by the time the flaring of chimney gas was scheduled to start (eight months after the detonation), or they were not considered to be biologically significant. It was assumed that the tritium would be partitioned between the hydrocarbons and the water in the vicinity of the detonation point, with about $30 \%$ of the tritium being incorporated into water. Actual results from the three U. S. gas stimulation experiments are briefly presented as follows:

Gasbuggy. Because a small amount of radioactive gas migrated up the cables from the Gasbuggy chimney and cavity, an early-time gas sample was obtained; however, the only radioactive species that could be immediately detected was ${ }^{133 \mathrm{~g}} \mathrm{Xe}$, which effectively "swamped out" the longer-lived species." However, later radiochemical results indicated that the major long-lived radionuclides present in the gas were ${ }^{85} \mathrm{Kr}$ and tritium. Also present were small amounts of ${ }^{14} \mathrm{C}$, ${ }^{37} \mathrm{Ar}$, and ${ }^{39} \mathrm{Ar}$.

*In this section all numbers quoted for concentrations of radioactivity have been corrected for radioactive decay to the detonation times of the respective experiments. 
Figure 8 plots the concentrations of a number of radioactive species present in the Gasbuggy chimney and cavity as a function of gas production. ${ }^{1}$ (All results have been decay-corrected to the time of detonation.) Examination of this figure reveals a marked similarity in the shape of the radioactive species concentration curves. This similarity is indicative that there was little or no compositional change in the gaseous radioactive species during the course of production testing. The shape of the curves is determined by the amount of diluent gas influx from the formation and the fraction of the radioactive species that remains in the chimney and cavity as production proceeds. These data have been used in interpreting production testing results, and also can allow an estimate to be made of the radioactivity remaining in the chimney and cavity system.

In order to determine how the tritium and ${ }^{14} \mathrm{C}$ present in the post-detonation environment are distributed among the various available hydrogen and carbon containing compounds, it is necessary to calculate the specific activities* of the tritium and ${ }^{14} \mathrm{C}$ in these compounds. It is convenient to express these specific activities in units of picocuries (of tritium or $\left.{ }^{14} \mathrm{C}\right)$ per standard millilitre of the gaseous chemical compound of interest. If the tritium-to-hydrogen ratio were a constant (tritium uniformly distributed in all hydrogen-containing compounds in the chimney and cavity), the specific activities of hydrogen, methane, ethane, and propane would exhibit a 1:2:3:4 ratio. On a similar basis, the specific activities of ${ }^{14} \mathrm{C}$ in $\mathrm{CO}_{2}$, $\mathrm{CH}_{4}$ and $\mathrm{CO}$ would all be expected to be the same. Table 3 lists specific activities of these compounds, and Fig. 9 plots selected data showing how specific activities vary as a function dry gas production from the chimney and cavity.

Two distinctively different behavior patterns are evident in Fig. 9. The specific activities of the tritiated alkanes are decreasing markedly, as would be expected as the chimney gases are diluted by inflowing formation gas. Note also from Table 3 that, considering the quoted errors, the ratios of the tritium specific activities of hydrogen, methane, and ethane are about as expected. However, the propane contains only about half as much tritium as would be predicted on the basis of a constant tritium-to-hydrogen ratio.

Because neither hydrogen nor carbon dioxide are present in appreciable quantities in the formation gas,

\footnotetext{
* The ratio of the radioactive isotope to the total amount of the element in a specific chemical compound.
}

TABLE 3. Gasbuggy: comparison of tritiated compounds and of compounds containing ${ }^{14} \mathrm{C}$-specific activities.

\begin{tabular}{lccc}
\hline & $\begin{array}{c}\text { Specific } \\
\text { activity } \\
(\mathrm{pCi} / \mathrm{ml})\end{array}$ & Normalized $^{\mathrm{b}}$ & $\begin{array}{c}\text { Expected Ratio } \\
\text { (assuming } \\
\text { uniform } \\
\text { distribution) }\end{array}$ \\
\hline $\mathrm{HT} / \mathrm{H}_{2}$ & $793 \pm 151$ & $1.33 \pm 0.26$ & 1 \\
$\mathrm{CH}_{3} \mathrm{~T} / \mathrm{CH}_{4}$ & $1191 \pm 30$ & 2.00 & 2 \\
$\mathrm{C}_{2} \mathrm{H}_{5} \mathrm{~T} / \mathrm{C}_{2} \mathrm{H}_{6}$ & $2078 \pm 110$ & $3.49 \pm 0.59$ & 3 \\
$\mathrm{C}_{3} \mathrm{H}_{7} \mathrm{~T} / \mathrm{C}_{3} \mathrm{H}_{8}$ & $1353 \pm 69$ & $2.27 \pm 0.37$ & 4 \\
${ }^{14} \mathrm{CO}_{2} / \mathrm{CO}_{2}$ & $5.26 \pm 1.43$ & 1.00 & 1 \\
${ }^{14} \mathrm{CH}_{4} / \mathrm{CH}_{4}$ & $0.925 \pm 0.594$ & $0.176 \pm 0.123$ & 1 \\
${ }^{14} \mathrm{CO}_{1} \mathrm{CO}^{-5.63} \pm 1.16$ & $1.07 \pm 0.36$ & 1 \\
\hline
\end{tabular}

a Average of all samples taken between $1 / 17 / 68$ and 4/22/68.

${ }^{b}$ Tritium-containing compounds normalized to $\mathrm{CH}_{3} \mathrm{~T} / \mathrm{CH}_{4}=2$; ${ }^{14} \mathrm{C}$-containing compounds normalized to ${ }^{14} \mathrm{CO}_{2} / \mathrm{CO}_{2}=1$.

dilution of these species during drawdown would not be expected to alter their specific activities. This behavior is indeed shown in Fig. 9.

While analyses of the tritiated water produced with the gas were carried out, the specific activity of the water (ratio $\mathrm{HTO} / \mathrm{H}_{2} \mathrm{O}$ ) varied widely. This was determined to have resulted from a significant flow of groundwater into the chimney and cavity from the Ojo Alamo aquifer, immediately above the top of the chimney. Hence, no conclusions could be drawn from the tritiated water data.

With respect to the distribution of ${ }^{14} \mathrm{C}$, it would appear from Table 2 that, while the ${ }^{14} \mathrm{C}$ had exchanged completely between $\mathrm{CO}_{2}$ and $\mathrm{CO}$, the exchange with the carbon of the alkanes (or more specifically, with the methane) was not complete. That is, the ${ }^{14} \mathrm{C}$ produced in the course of the nuclear detonation was more available to the $\mathrm{CO}_{2}$ released as the rocks surrounding the explosion were thermally decomposed than it was to organic species.

The ${ }^{37} \mathrm{Ar}$ produced by the nuclear reaction ${ }^{40} \mathrm{Ca}(1 \mathrm{n}, \alpha),{ }^{37} \mathrm{Ar}$, and ${ }^{39} \mathrm{Ar}$ produced by ${ }^{39} \mathrm{~K}(\mathrm{n}, \mathrm{p}){ }^{39} \mathrm{Ar}$ were also found to be present in the Gasbuggy gas. Although the amount of ${ }^{37} \mathrm{Ar}$ in the gas at detonation time vas relatively large (calculated to be $4720 \mathrm{pCi} / \mathrm{ml}$ at STP), because of its short half-life ( $35 \mathrm{~d}$ ), it did not represent a gas quality problem. Likewise, the ${ }^{39} \mathrm{Ar}$, with a concentration of $0.0844 \mathrm{pCi} / \mathrm{ml}$ at STP, was consiclered to be only a minor radioactive constituent of the chimney gas.

The initial concentration of ${ }^{85} \mathrm{Kr}$ (the only longlived fission product detected in the Gasbuggy gas) was $119 \mathrm{pCi} / \mathrm{ml}$. 


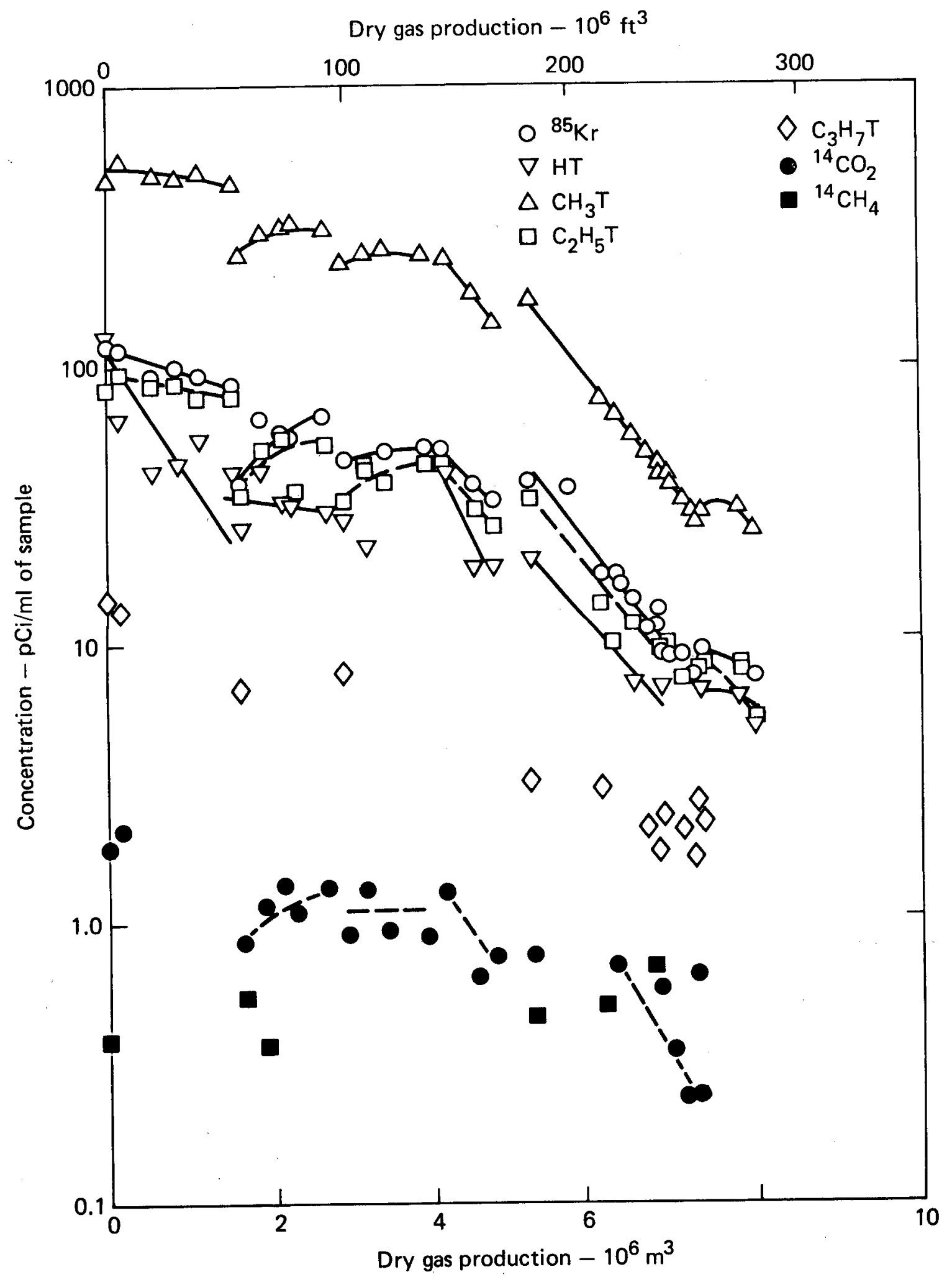

FIG. 8. Concentration of principal radioactive species during Project Gasbuggy production testing plotted as a function of dry gas produced (line segments define the six production test periods). 


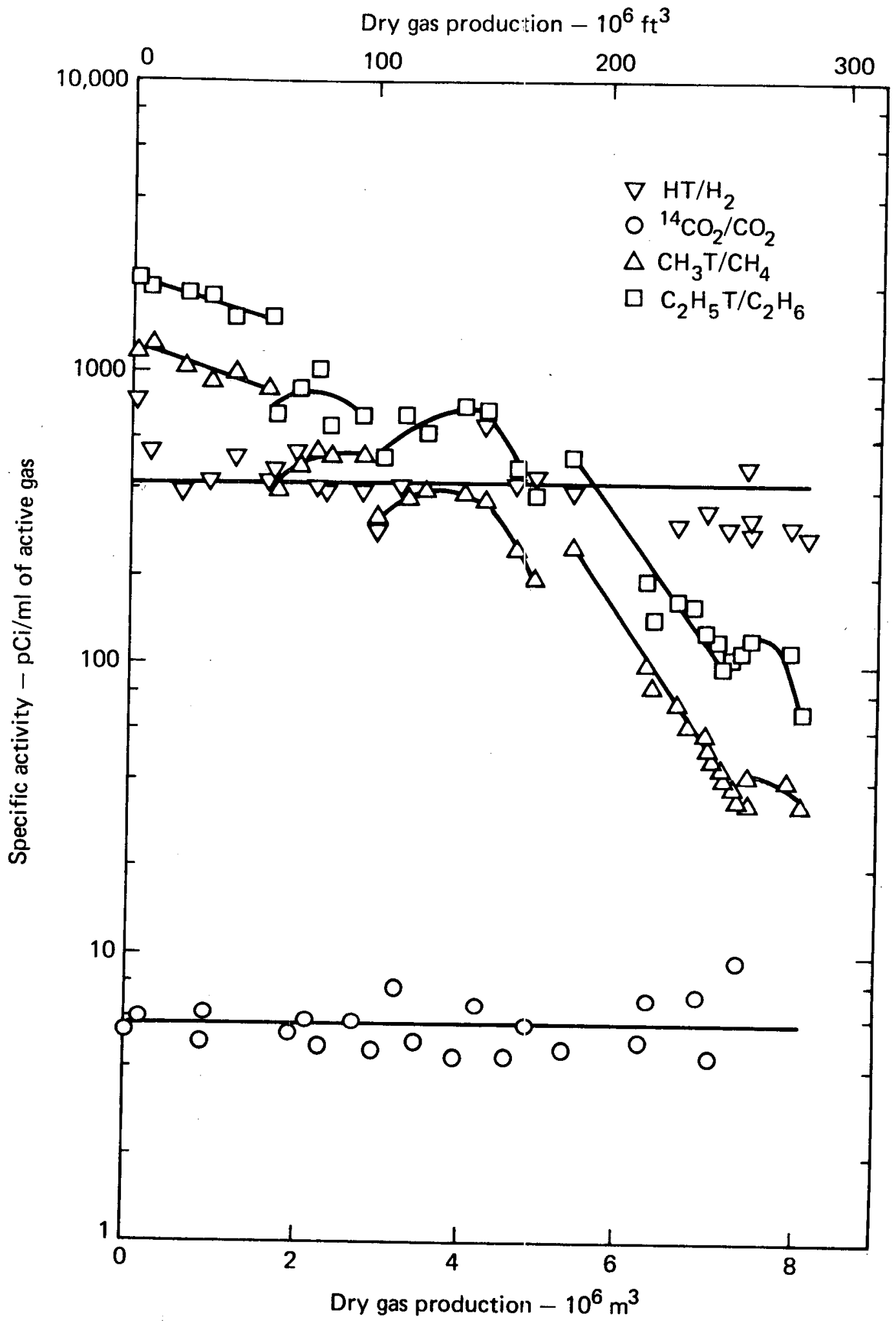

FIG. 9. Specific activity of selected chimney gas components (luring production testing at Project Gasbuggy plotted as a function of dry gas production (solid line segments define the six production test periods). 
As was noted earlier, it was considered possible that some gaseous compound containing ${ }^{131} \mathrm{l}$ could be present in the chimney gas. Consequently, this radionuclide, as well as a number of other radioactive species, was searched for by gamma counting a gas sample about 40 days after the Gasbuggy detonation. ${ }^{1,12}$ No radioactivity was detected other than those species previously discussed and some naturally occurring ${ }^{222} \mathrm{Rn}$; the sensitivity of the detection system was used to estimate the probable upper concentration limits of a number of radionuclides in the gas (see Table 4).

In addition, a relatively large volume of chimney gas was passed through a filter to determine the amount of long-lived radioactivity that could be associated with particulates in the gas. This allowed upper limits to be estimated for ${ }^{90} \mathrm{Sr}$ and ${ }^{137} \mathrm{Cs}$ as shown in Table 5.

Rulison. The same radioactive species present in the Gasbuggy gas were detected in the Rulison experiment. Figure 10 plots the concentrations of a number of these species as a function of gas production. ${ }^{2}$ As in the case of Gasbuggy, the concentrations of all the compounds shown in Fig. 10 change in a very similar way with increasing total production of dry gas, indicating that no compositional changes are occurring due to exchange interactions.

TABLE 4. Probable upper limits for nongaseous radionuclide concentrations in femtocuries ${ }^{2}$ per standard $\mathrm{cm}^{3}$ of chimney gas at $\mathbf{t}_{0}$.

\begin{tabular}{lcc}
\hline Nuclide & Experimental & Probable $^{\mathrm{b}}$ \\
\hline${ }^{127} \mathrm{Sb}$ & 2000. & 80. \\
${ }^{131} \mathrm{I}$ & 40. & 40. \\
${ }^{125} \mathrm{Sn}$ & 2000. & 30. \\
${ }^{129} \mathrm{~m}_{\mathrm{Te}}$ & 1. & 1. \\
${ }^{103} \mathrm{Ru}$ & 0.08 & 0.8 \\
${ }^{125 \mathrm{~m}_{\mathrm{Te}}}$ & 0.7 & 0.6 \\
${ }^{127} \mathrm{Te}$ & - & 0.4 \\
${ }^{123} \mathrm{Sn}$ & 20. & 0.3 \\
${ }^{106} \mathrm{Ru}$ & 0.1 & 0.09 \\
${ }^{125} \mathrm{Sb}$ & 0.2 & 0.03 \\
${ }^{90} \mathrm{Sr}$ & $>4000$. & 0.03 \\
${ }^{137} \mathrm{Cs}$ & 0.01 & 0.03 \\
\hline
\end{tabular}

${ }_{10}^{3}$ femtocuries $=1$ picocurie.

brobable concentration assumes the number of atoms of a given radionuclide is equal to (or less than) the number of ${ }^{131_{1}}$ atoms in the chimney gas at any given time.
TABLE 5. Gasbuggy filter paper results (in counts/min).

\begin{tabular}{lccc} 
& $\begin{array}{c}\text { Sample } \\
\left(38.5 \mathrm{~m}^{3}\right)\end{array}$ & $\begin{array}{c}\text { Background } \\
\left(1.06 \mathrm{~m}^{3}\right)\end{array}$ & Net \\
\hline${ }^{90} \mathrm{Sr}$ & $1.32 \pm 0.15$ & $1.36 \pm 0.16$ & $-0.04 \pm 0.23$ \\
${ }^{137} \mathrm{Cs}$ & $0.91 \pm 0.15$ & $1.08 \pm 0.15$ & $-0.18 \pm 0.21$ \\
\hline
\end{tabular}

The specific activities of these chemical species are shown in Fig. 11; ethane and propane, though not plotted in Fig. 11, exhibit the same behavior as methane. While the change in the specific activities of hydrogen and methane as a function of the total of dry gas produced display the same characteristics in both the Rulison and Gasbuggy experiments, $\mathrm{CO}_{2}$ is clearly different. On Gasbuggy, the specific activity was constant, while for Rulison, it drops by a factor of about seven. The reason for this will be discussed later.

Table 6 gives the relative tritium-to-hydrogen ratios for a number of chemical species in the Rulison chimney. Note the similarity to the Gasbuggy results, as shown in Table 3.

Because the water released by the Rulison explosion was not diluted by water from any other source, its specific activity remained relatively constant during production testing at $0.4 \pm 0.1 \mu \mathrm{Ci} / \mathrm{cm}^{3}$ of liquid water (this is equivalent to $320 \pm 80 \mathrm{pCi} / \mathrm{ml}$ of water vapor at STP, as shown in Table 6).

Note that ${ }^{14} \mathrm{C}$ was determined only in the form of ${ }^{14} \mathrm{CO}_{2}$; the amount present as ${ }^{14} \mathrm{CH}_{4}$ is not known.

Initial concentration of ${ }^{37} \mathrm{Ar}$ in the Rulison gas was $6700 \mathrm{pCi} / \mathrm{ml}$ (STP); the concentration of ${ }^{39} \mathrm{Ar}$ was $1.5 \mathrm{pCi} / \mathrm{ml}$ (STP).

The ${ }^{85} \mathrm{Kr}$ initial concentration was $150 \mathrm{pCi} / \mathrm{ml}$ in the Rulison gas.

Rio Blanco. The expected radioactive species were detected in the gas from both the top and bottom Rio Blanco chimneys. Figure 12 plots the concentrations of a number of these species as a fraction of dry gas production for the top and bottom chimneys, ${ }^{3,4}$. In the case of the top chimney, it can be seen that the concentrations of the ${ }^{37} \mathrm{Ar},{ }^{85} \mathrm{Kr}$, and $\mathrm{CH}_{3} \mathrm{~T}$ all change in a very similar way, dropping off as the chimney gas is produced and the remaining gas is diluted with incoming formation gas (although $\mathrm{C}_{2} \mathrm{H}_{5} \mathrm{~T}$ and $\mathrm{C}_{3} \mathrm{H}_{7} \mathrm{~T}$ are not plotted in this figure, they behave much the same as the $\mathrm{CH}_{3} \mathrm{~T}$ ). However, both the $\mathrm{HT}$ and ${ }^{14} \mathrm{CO}_{2}$ clearly display different characteristics from the other radioactive species, with the ${ }^{14} \mathrm{CO}_{2}$ actually seeming to increase in concentration as more gas is produced. Apparently, this is a real effect, since analytical errors are 
TABLE 6. Comparison of Project Rulison tritiated compounds - specific activities.

\begin{tabular}{|c|c|c|c|}
\hline Compound & $\begin{array}{c}\text { Specific activity } \\
(\mathrm{pCi} / \mathrm{ml}) \\
\end{array}$ & to $\begin{array}{c}\text { Normalized } \\
\mathrm{CH}_{3} \mathrm{~T} / \mathrm{CH}_{4}=2\end{array}$ & $\begin{array}{c}\text { Expected ratio, } \\
\text { assuming equal T/H } \\
\text { (high-temperature) }\end{array}$ \\
\hline $\mathrm{HT} / \mathrm{H}_{2}$ & $125 \pm 3^{a}$ & $0.56 \pm 0.02$ & 1 \\
\hline $\mathrm{HTO} / \mathrm{H}_{2} \mathrm{O}$ & $320 \pm 80$ & $1.45 \pm 0.4$ & 1 \\
\hline $\mathrm{CH}_{3} \mathrm{~T} / \mathrm{CH}_{4}$ & $442 \pm 8^{b}$ & 2.00 & 2 \\
\hline $\mathrm{C}_{2} \mathrm{H}_{5} \mathrm{~T} / \mathrm{C}_{2} \mathrm{H}_{6}$ & $610 \pm 10^{b}$ & $2.76 \pm 0.05$ & 3 \\
\hline $\mathrm{C}_{3} \mathrm{H}_{7} \mathrm{~T} / \mathrm{C}_{3} \mathrm{H}_{8}$ & $620 \pm 50^{b}$ & $2.80 \pm 0.2$ & 4 \\
\hline
\end{tabular}

${ }^{a}$ Average of all samples.

b Average calibration flaring plus first high-rate test sample.

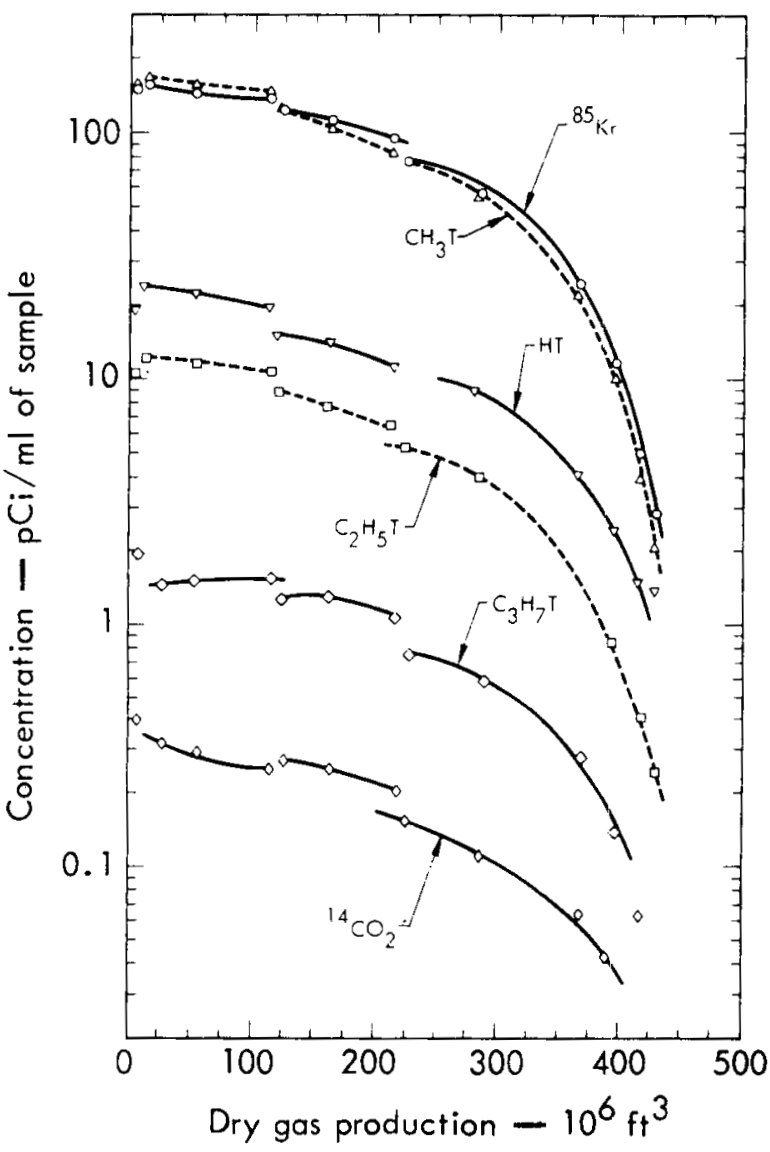

FIG. 10. Concentration of principal radionuclides during Project Rulison production testing plotted as a function of dry gas produced (data points at $5 \times 10^{6} \mathrm{ft}^{3}$ are average of five samples collected during calibration flaring; solid line segments define the three production test periods) - taken from Ref. 2 .

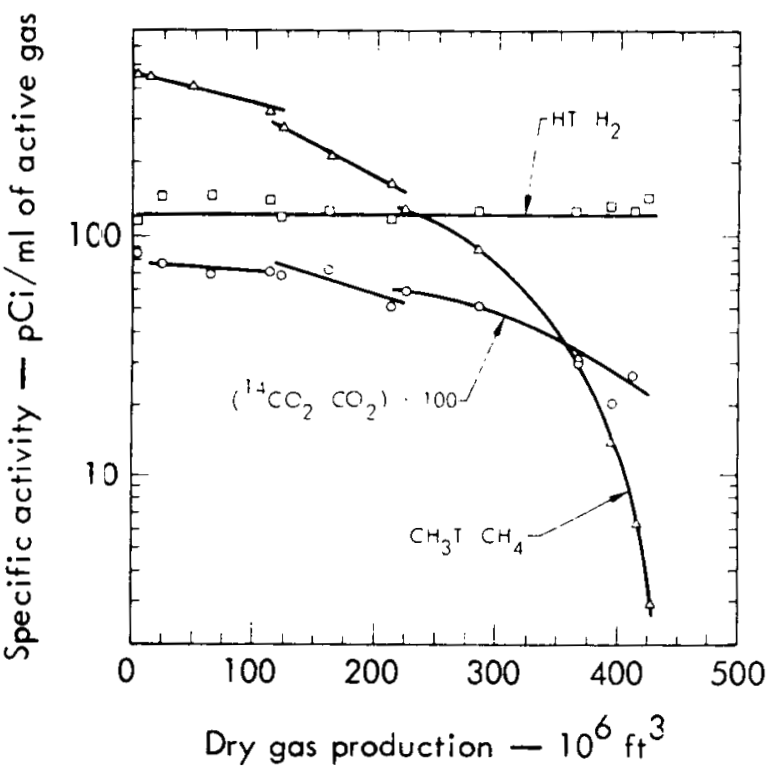

FIG. 11. Specific activity of selected chimney gas components during production testing at Project Rulison plotted as a function of dry gas production (data points at $5 \times 10^{6} \mathrm{ft}^{3}$ are the average of five samples collected during calibration flaring; solid-line segments define the three production test periods) taken from Ref. 2. 


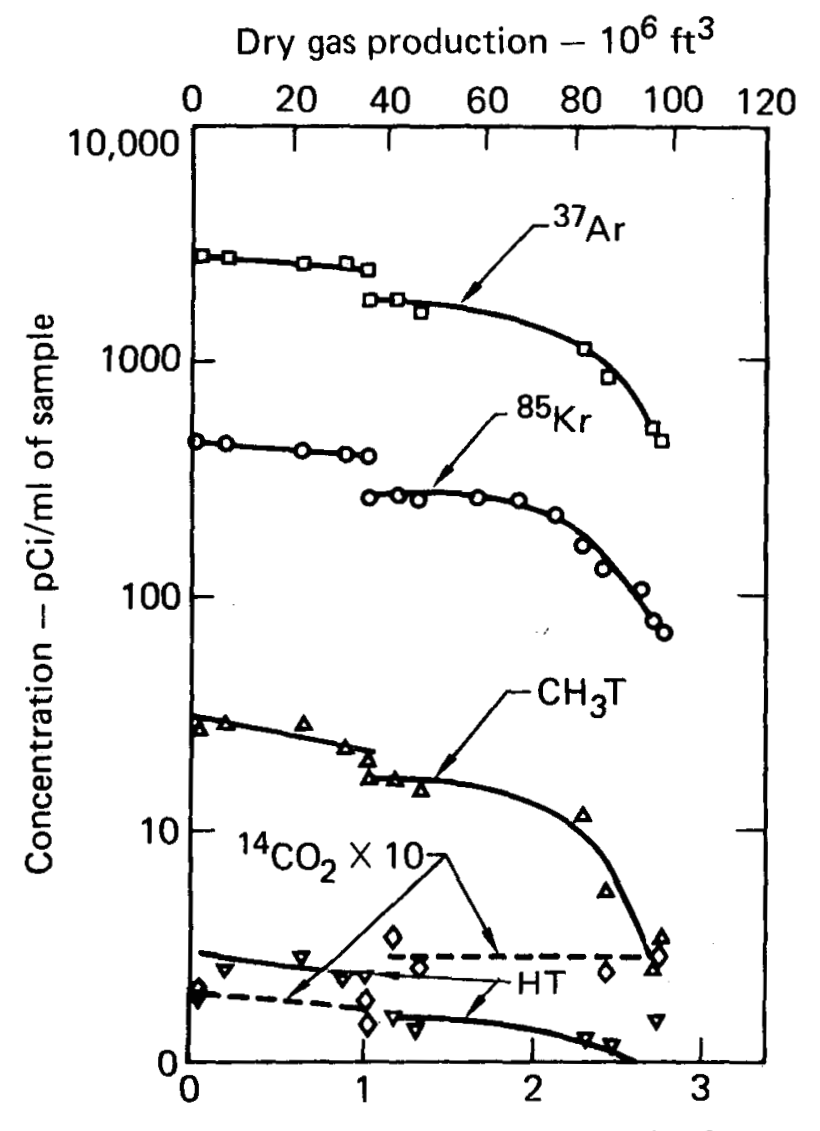

Dry gas production $-10^{6} \mathrm{~m}^{3}$

FIG. 12a. Concentration of principal radioactive species during Project Rio Blanco production testing of top chimney plotted as a function of dry gas produced (line segments define the two production test periods).

small as compared with the observed variations. Note also that the concentrations of all species measured are very similar for the two chimneys. The behavior of the lower chimney radioactivity concentrations as a function of gas produced seems to be somewhat similar to that observed for the upper chimney; however, the production testing of the lower chimney was terminated before this observation could be satisfactorily verified.

The specific activities of four chemical species are shown for both chimneys in Fig. 13; propane generally behaves much the same as methane and ethane. It can be seen that, while the specific activities of the tritiated alkanes drop as a function of the amount of gas produced (as was seen in both the Gasbuggy and Rulison experiments), at least in the case of the upper chimney

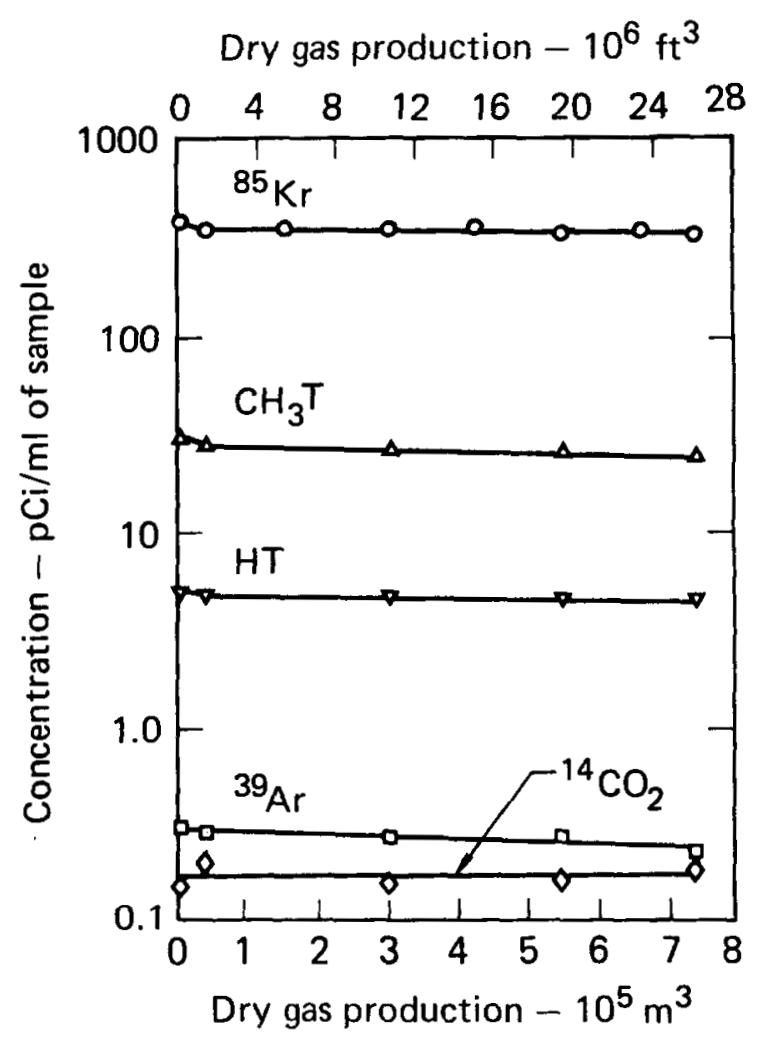

FIG. 12b. Concentration of principal radioactive species during Project Bio Blanco production testing of bottom chimney plotted as a function of dry gas produced.

the specific activity of the hydrogen actually seems to increase. Likewise, the specific activity of the $\mathrm{CO}_{2}$ shows an increase. It is not clear whether the lower chimney would have behaved in a similar way, since insufficient data were obtained during the relatively' limited production test. Possible explanations for this behavior will be presented later in this section.

Table 7 gives the relative tritium-to-hydrogen ratios for a number of tritiated species in the Rio Blanco chimneys. The results are somewhat similar to those reported for the Gasbuggy and Rulison projects; while the tritium does not appear to be uniformly distributed, the relative distribution among the listed chemical species appears to be quite consistent for all three experiments. 


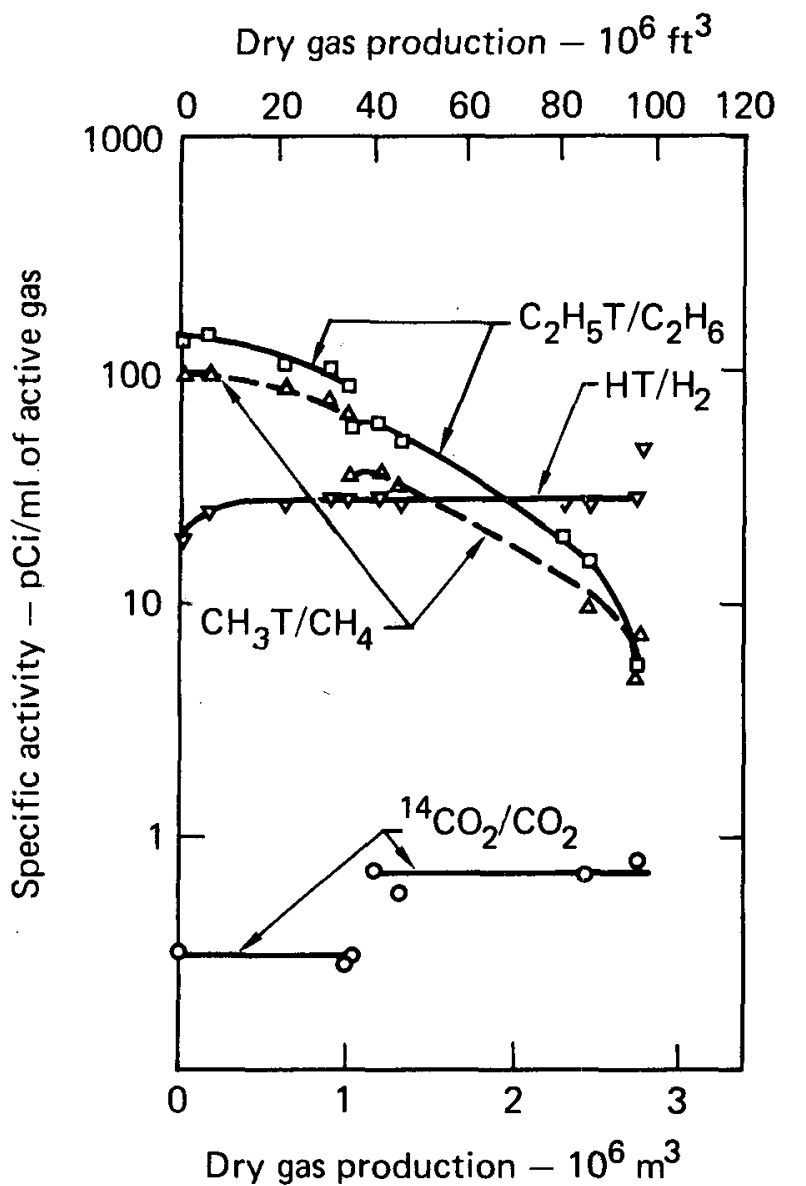

FIG. 13a. Specific activity of selected chimney gas components during production testing of top chimney at Project Rio Blanco plotted as a function of dry gas production (line segments define the two production test periods).

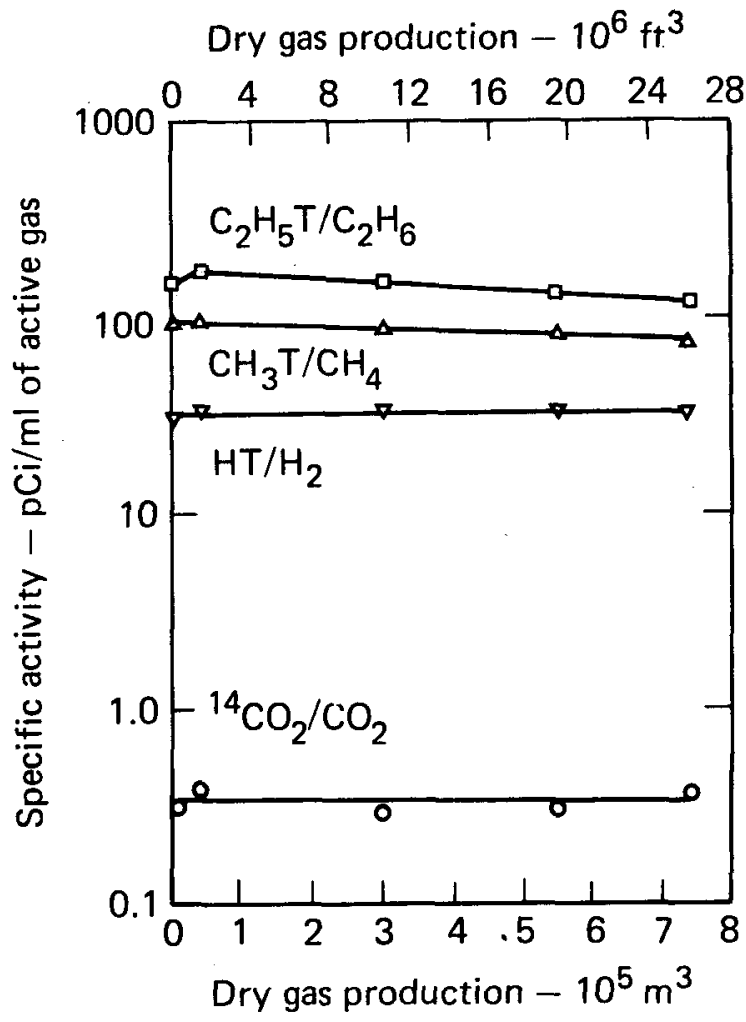

FIG. 13b. Specific activity of selected chimney gas compronents during testing of bottom chimney at Project Rio Blanco plotted as a function of dry gas production.

TABLE 7. Rio Blanco: Comparison of specific activities of tritiated compounds (top and bottom chimneys).

\begin{tabular}{|c|c|c|c|c|c|}
\hline \multirow[b]{2}{*}{ Compound } & \multicolumn{2}{|c|}{ Top chimney } & \multicolumn{2}{|c|}{ Bottom chimney } & \multirow[b]{2}{*}{$\begin{array}{c}\text { Expected ratio } \\
\text { (assuming } \\
\text { uniform } \\
\text { distribution) }\end{array}$} \\
\hline & $\begin{array}{l}\text { Specific } \\
\text { activity }^{\mathrm{a}} \\
(\mathrm{pCi} / \mathrm{ml})\end{array}$ & Normalized $^{\mathbf{b}}$ & $\begin{array}{l}\text { Specific } \\
\text { activity } \\
\text { (pCi/ml) }\end{array}$ & Normalized & \\
\hline \multirow[t]{2}{*}{$\mathrm{HT} / \mathrm{H}_{2}$} & $18.1 \pm 2.9$ & $0.38 \pm 0.10$ & $32.7 \pm 1.4^{c}$ & $0.68 \pm 0.07$ & 1 \\
\hline & $(27.6 \pm 1.0)^{d}$ & $(0.58 \pm 0.11)$ & & & \\
\hline $\mathrm{HTO} / \mathrm{H}_{2} \mathrm{O}$ & $56 \pm 13^{\mathrm{e}}$ & $1.18 \pm 0.36$ & $70 \pm 5^{f}$ & $1.45 \pm 0.18$ & 1 \\
\hline $\mathrm{CH}_{3} \mathrm{~T} / \mathrm{CH}_{4}$ & $94.8 \pm 18.2$ & 2.00 & $96.5 \pm 9.7$ & 2.00 & 2 \\
\hline $\mathrm{C}_{2} \mathrm{H}_{5} \mathrm{~T} / \mathrm{C}_{2} \mathrm{H}_{6}$ & $134 \pm 15$ & $2.83 \pm 0.63$ & $167 \pm 16$ & $3.46 \pm 0.48$ & 3 \\
\hline $\mathrm{C}_{3} \mathrm{H}_{7} \mathrm{~T} / \mathrm{C}_{3} \mathrm{H}_{8}$ & $175 \pm 35^{g}$ & $3.69 \pm 1.02$ & $82.3 \pm 7.9$ & $1.70 \pm 0.24$ & 4 \\
\hline
\end{tabular}

${ }^{a}$ Average of all samples taken between $10 / 17 / 73$ and 10/25/73.

${ }^{\text {b }}$ Normalized to $\mathrm{CH}_{3} \mathrm{~T} / \mathrm{CH}_{4}=2$.

c Average of samples taken on $11 / 2 / 74$ and $12 / 10 / 74$.

d Average of all samples taken between $11 / 18 / 73$ and $2 / 14 / 74$.

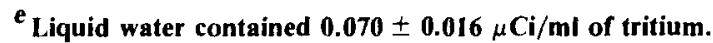

${ }^{f}$ Liquid water contained $0.087 \pm 0.006 \mu \mathrm{Ci} / \mathrm{ml}$ of tritium.

grom sample $72-1-14-70$ of 10/17/73 only. 
As in the case of Rulison, the water released by the Rio Blanco detonations was not diluted by water from any other sources, and thus the specific activity remained relatively constant during production testing from both cavities. Note that the specific activity of the water was essentially the same (within the experimental error) for both Rio Blanco cavities.

The amount of ${ }^{14} \mathrm{C}$ present in $\mathrm{CO}_{2}$ was determined for both upper and lower chimneys; the average concentration during the first production tests of these chimneys was $0.18 \mathrm{pCi} / \mathrm{ml}$ in both cases. However, during the second production run from the upper chimney, the concentration rose to $0.29 \mathrm{pCi} / \mathrm{ml}$. Whether further production from the lower chimney would have shown the same effect cannot be predicted. The concentration of ${ }^{14} \mathrm{C}$ present in the alkanes was not determined.

The ${ }^{37} \mathrm{Ar}$ concentration was initially $2870 \mathrm{pCi} / \mathrm{ml}$ in the upper chimney, while the ${ }^{39} \mathrm{Ar}$ concentration in the lower chimney was about $0.32 \mathrm{pCi} / \mathrm{ml}$. Note that ${ }^{39} \mathrm{Ar}$ was never determined in the upper chimney gas, and by the time of lower chimney reentry essentially all of the ${ }^{37} \mathrm{Ar}$ had decayed.

Of course, ${ }^{85} \mathrm{Kr}$ was detected in the cavity gas; initial concentrations were $450 \mathrm{pCi} / \mathrm{ml}$ and $251 \mathrm{pCi} / \mathrm{ml}$ in the top and bottom chimneys, respectively.

The top chimney was re-entered when there was still some ${ }^{131 \mathrm{~m}} \mathrm{Xe}$ present; the initial concentration of this nuclide was $39,700 \mathrm{pCi} / \mathrm{ml}$.

Summary. The concentrations of the principal radioactive species present initially (before production testing) in the cavity and chimney gas of the three gas stimulation experiments are shown in Table 8 .

An examination of Table 8 indicates a number of similarities and differences among the three projects:

- ${ }^{85} \mathrm{Kr}$ concentrations vary by only about a factor of four. These concentrations are indicative of the amount of dry gas available in the chimney to mix with the ${ }^{85} \mathrm{Kr}$ produced by fission; the larger values in Rio Blanco are the result of the large amount of steam present in the chimneys that limited the amount of dry gas present.

- Tritium-containing species successively decrease in concentration from Gasbuggy to Rio Blanco due mainly to the progressive decrease in the amount of tritium produced by the different explosives.

- The concentrations of ${ }^{14} \mathrm{CO}_{2}$ in the gas reflect a progressively decreasing (from Gasbuggy to Rio Blanco) activation of nitrogen by neutrons from the explosives (from the ${ }^{14} \mathrm{~N}(\mathrm{n}, \mathrm{p}){ }^{14} \mathrm{C}$ reaction). This decreasing activation is probably due to a smaller
TABLE 8. Initial radioactivity concentration in cavity gas of nuclearly stimulated wells.

\begin{tabular}{lcccc}
\hline & \multicolumn{3}{c}{ Concentration $(\mathrm{pCi} / \mathrm{ml})^{\mathrm{a}}$} \\
\cline { 2 - 5 } Chemical & & & \multicolumn{2}{c}{ Rio Blanco } \\
\cline { 2 - 5 } species & Gasbuggy & Rulison & $\begin{array}{c}\text { Top } \\
\text { chimney }\end{array}$ & $\begin{array}{c}\text { Bottom } \\
\text { chimney }\end{array}$ \\
\hline${ }^{85}{ }_{\mathrm{Kr}}$ & 119 & 150 & 450 & 251 \\
$\mathrm{HT}$ & 144 & 18.5 & 1.86 & 4.96 \\
& & & $(2.50)^{\mathrm{b}}$ & \\
$\mathrm{CH}_{3} \mathrm{~T}$ & 463 & 145 & 27.0 & 29.2 \\
${ }_{2} \mathrm{H}_{5} \mathrm{~T}$ & 81.2 & 10.5 & 0.87 & 3.33 \\
${ }_{3}{ }_{3} \mathrm{H}_{7} \mathrm{~T}$ & 14.5 & 1.9 & 0.07 & 0.22 \\
${ }^{14} \mathrm{CO}_{2}$ & 1.93 & 0.41 & 0.18 & 0.18 \\
& & & $(0.29)$ & \\
${ }^{14}{ }_{\mathrm{CH}}$ & 0.352 & - & - & - \\
${ }^{37}{ }_{\mathrm{Ar}}$ & 4720 & 6700 & 2,820 & - \\
${ }^{39}{ }_{\mathrm{Ar}}$ & 0.0844 & 1.5 & - & 0.32 \\
${ }_{131 \mathrm{~m}_{\mathrm{Xe}}}$ & - & - & 39,700 & - \\
\hline
\end{tabular}

${ }^{\text {a }}$ Dry basis

${ }^{b}$ Value obtained from first production test.

c Value obtained from second production test.

emergent neutron flux from the Rulison and Rio Blanco explosives, but could also be caused by smaller amounts of nitrogen in the explosive environments.

- The concentrations of ${ }^{37} \mathrm{Ar}$ and ${ }^{39} \mathrm{Ar}$ are affected by the amounts of calcium and potassium, respectively, in the explosive environments, and are also affected by the number and energy spectra of the neutrons emitted by the explosives.

\section{CONCENTRATION CHANGES IN MAJOR GASEOUS COMPONENTS}

Because all of the ${ }^{85} \mathrm{Kr}$ produced by the nuclear explosive is assumed to be present in the chimney gas following the detonation, the rate at which the ${ }^{85} \mathrm{Kr}$ concentration in the gas decreases is a measure of the rate of dilution of the chimney gas by formation gas. Presumably, the rate of dilution of such reaction production gases as $\mathrm{H}_{2}$ and $\mathrm{CO}_{2}$ (which are essentially not present in the formation gas) should be the same as that of the ${ }^{85} \mathrm{Kr}$. This hypothesis can be tested by determining the ratio of $\mathrm{H}_{2}$ and $\mathrm{CO}_{2}$ concentrations, respectively, to that of ${ }^{85} \mathrm{Kr}$ as a function of total gas production.

Gasbuggy. In Fig. 14, the concentration ratios of $\mathrm{H}_{2}, \mathrm{CO}_{2}$, and $\mathrm{CH}_{4}$ to ${ }^{85} \mathrm{Kr}$ are plotted as a function of 


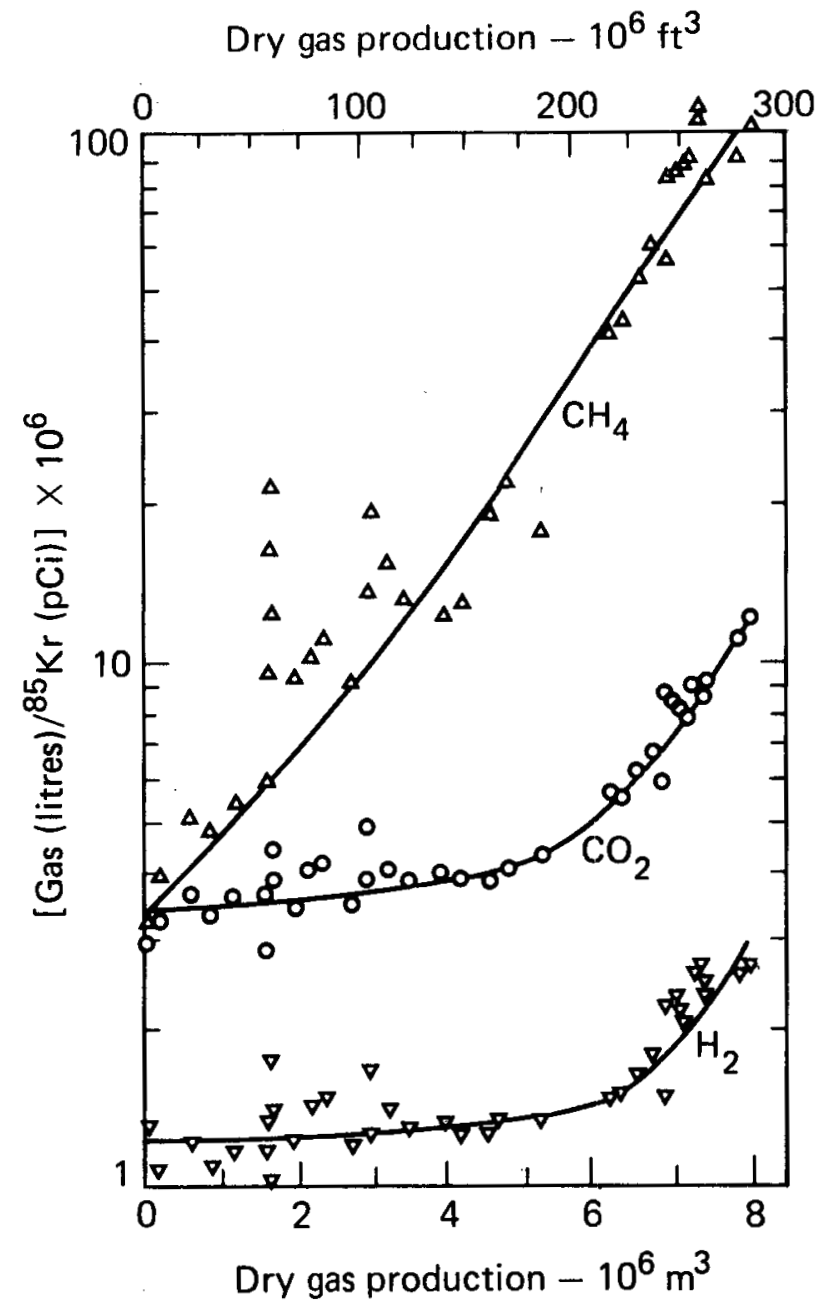

FIG. 14. Ratio of selected chimney gas components to ${ }^{85} \mathrm{Kr}$ during production testing at Project Gasbuggy plotted as a function of dry gas produced.

total dry gas production. As would be expected, the $\mathrm{CH}_{4} /{ }^{85} \mathrm{Kr}$ ratio increases rapidly as fresh $\mathrm{CH}_{4}$ from the formation gas enters the chimney. However, both the $\mathrm{CO}_{2-}$ and $\mathrm{H}_{2}$-to- ${ }^{85} \mathrm{Kr}$ ratios also display modest increases, apparently indicating that both gases are being diluted with time. A possible explanation for the apparent late-time generation of the gases could involve the ebullition of dissolved $\mathrm{CO}_{2}$ and $\mathrm{H}_{2}$ from water in the chimney as gas pressures decrease during the course of production testing. In this case, the evolved gases would display the same specific activity as the gases already in the chimney - as is, in fact, the case as can be seen from Fig. 9. Continued generation of $\mathrm{CO}_{2}$ by relatively high-temperature reactions between carbonate and silicate minerals has been suggested as a mechanism by Taylor ${ }^{13}$; however, the evolved $\mathrm{CO}_{2}$ would contain no ${ }^{14} \mathrm{C}$, and, hence, the specific activity of the $\mathrm{CO}_{2}$ would be expected to drop as a function of time. This effect was not observed. Still a third mechanism has been postulated: if some $\mathrm{CO}_{2}$ and $\mathrm{H}_{2}$ were driven into the walls of the cavity at early times following the detonation when the chimney and cavity system was at a relatively high pressure, then they would bleed back into the chimney at late times when the gas pressure has decreased. However, this explanation fails, because the ${ }^{85} \mathrm{Kr}$ would also be expected to be present with the $\mathrm{CO}_{2}$ and $\mathrm{H}_{2}$ in the cracks of the chimney walls, and there would be little or no change in the $\mathrm{CO}_{2} /{ }^{85} \mathrm{Kr}$ and $\mathrm{H}_{2} /{ }^{85} \mathrm{Kr}$ ratios as a function of gas production.

Thus, the first mechanism (ebullition of dissolved gases from water in the chimney) appears to be the most likely on the basis of experimental observations. Note that krypton is much less soluble in water than are either $\mathrm{CO}_{2}$ or $\mathrm{H}_{2}$, which fact also tends to strengthen this hypothesis.

The absolute quantities of the various gases in the chimney can be estimated by performing a regression analysis between the total ${ }^{85} \mathrm{Kr}$ remaining in the chimney as a function of gas produced and the total of the species in question that remains in the chimney, also as a fraction of gas produced. This method is discussed in some detail by Smith ${ }^{2}$. As indicated in Ref. 2, this approach requires a knowledge of the total ${ }^{85} \mathrm{Kr}$ initially present in the chimney. For Gasbuggy, this has been estimated to be $750 \pm 20 \mathrm{Ci}$ corrected to detonation lime. ${ }^{6}$

The results of the calculations of total $\mathrm{H}_{2}$ and $\mathrm{CO}_{2}$ remaining in the Gasbuggy chimney are displayed graphically in Fig. 15 and Fig. 16, respectively. The weighted data have been fitted to the general equation:

$$
\text { Gas }=m\left({ }^{85} \mathrm{Kr}\right)+\mathrm{b} \text {, }
$$

where $m$ is the slope of the line and $b$ is the intercept when ${ }^{85} \mathrm{Kr}$ is zero. Here, $\mathrm{b}$ represents the quantity of gas not initially mixed with ${ }^{85} \mathbf{K r}$.

Results of the least-squares fit to the data can be expressed as:

$$
\begin{aligned}
& \mathrm{H}_{2}\left(10^{9}\right. \text { litres } \\
& \quad \mathrm{STP})=(1.14 \pm 0.07) \times 10^{-3} \\
& \quad \times\left({ }^{85} \mathrm{Kr} \mathrm{Ci}\right)+(1.97 \pm 1.24) \times 10^{-2} \\
& \mathrm{CO}_{2}\left(10^{9} \text { litres STP }\right)=(3.11 \pm 0.18) \times 10^{-3} \\
& \times\left({ }^{85} \mathrm{Kr} \mathrm{Ci}\right)+(9.31 \pm 3.63) \times 10^{-2} .
\end{aligned}
$$

Thus, $(2.0 \pm 1.2) \times 10^{7}$ litres (STP) of $\mathrm{H}_{2}$ and $(9.3 \pm$ 3.6) $\times 10^{7}$ litres (STP) of $\mathrm{CO}_{2}$ are present in excess of that initially mixed with ${ }^{85} \mathrm{Kr}$. This amount of $\mathrm{H}_{2}$ is 


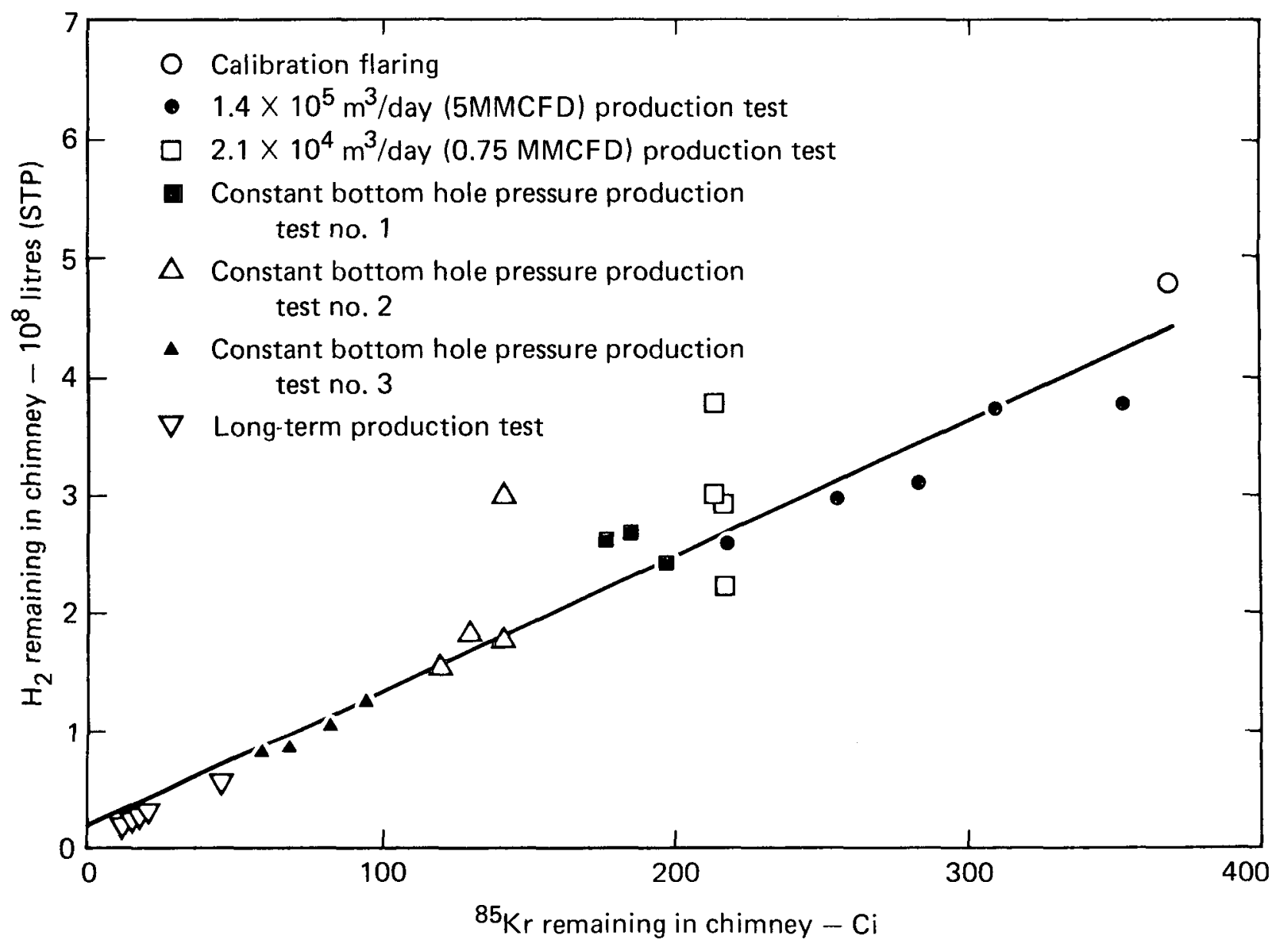

FIG. 15. Remaining $\mathrm{H}_{2}$ in Gasbuggy chimney as a function of remaining ${ }^{85} \mathrm{Kr}$.

( $4.5 \pm 2.8) \%$ of the $4.4 \times 10^{8}$ litres of $\mathrm{H}_{2}$ present before production, and is statistically different from zero.* In the case of $\mathrm{CO}_{2}$, the incremented amount is $(7.5 \pm$ $2.9) \%$ of the $1.24 \times 10^{9}$ litres of $\mathrm{CO}_{2}$ present in the preproduction chimney gas - again an amount that is statistically different from zero.

Rulison. The concentration ratios of $\mathrm{H}_{2}, \mathrm{CO}_{2}$, and $\mathrm{CH}_{4}$ to ${ }^{85} \mathrm{Kr}$ are shown as a function of total dry gas production in Fig. 17. As is the case of Gasbuggy, the $\mathrm{CH}_{4}$-to- ${ }^{85} \mathrm{Kr}$ ratio rises rapidly, with the $\mathrm{CO}_{2}$-to${ }^{85} \mathrm{Kr}$ ratio rising somewhat more slowly. However, for Rulison, the $\mathrm{H}_{2}$-to- ${ }^{85} \mathrm{Kr}$ ratio changes only slightly with dry gas production, indicating that the hydrogen in the chimney is not being significantly diluted with time.

From the data in Fig. 17 together with the data in Fig. 11 (specific activity of various species as a function of gas production), there appear to be significant differences between Rulison and Gasbuggy. While the

*Greater than about $95 \%$ probability of being nonzero.
$\mathrm{H}_{2}$ appears to behave in a fairly similar way for both events (with the specific activity essentially constant over the total range of gas production), the behavior of the $\mathrm{CO}_{2}$ specific activity on Rulison indicates that the additional $\mathrm{CO}_{2}$, which is presumably being produced during the course of the Rulison production testing, has a lower specific activity than did the $\mathrm{CO}_{2}$ in the original chimney gas. Thus, the ebullition mechanism seems less suitable for explaining the Rulison observations, and the continued late-time generation of $\mathrm{CO}_{2}$ may well be the result of continuing hightemperature reactions between carbonate and silicate minerals taking place in the hot rock near the detonation point.

Regression analyses relating the amounts of $\mathrm{H}_{2}$ and $\mathrm{CO}_{2}$ remaining in the Rulison chimney to the remaining ${ }^{85} \mathrm{Kr}$ in the chimney were carried out on the data shown in Figs 18 and 19, respectively. The total amount of ${ }^{85} \mathrm{Kr}$ produced by the Rulison detonation, as used in these calculations, was $1100 \pm 20 \mathrm{Ci}$ (Ref. 2). 


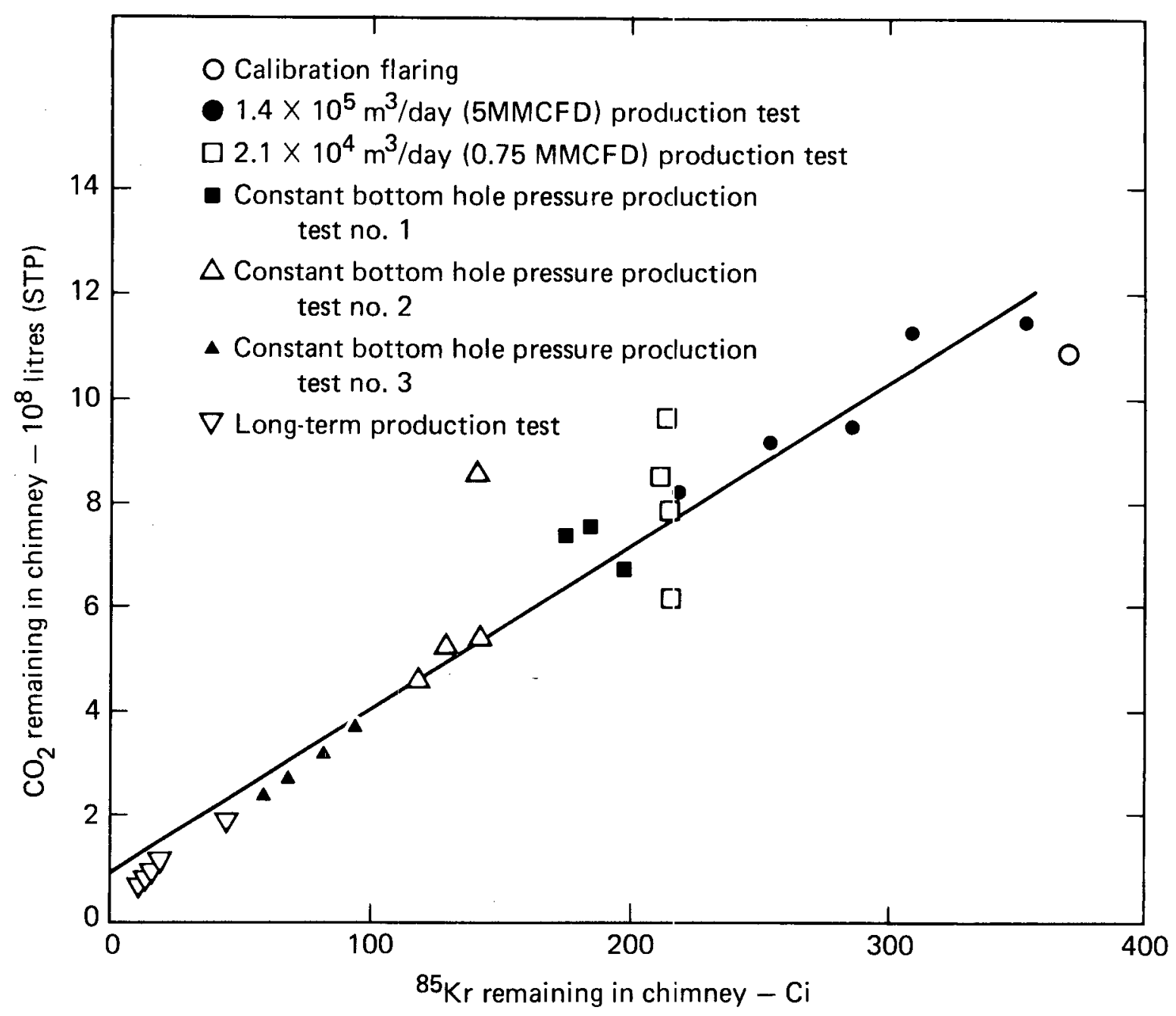

FIG. 16. Remaining $\mathrm{CO}_{2}$ in Gasbuggy chimney as a function of remaining ${ }^{85} \mathrm{Kr}$.

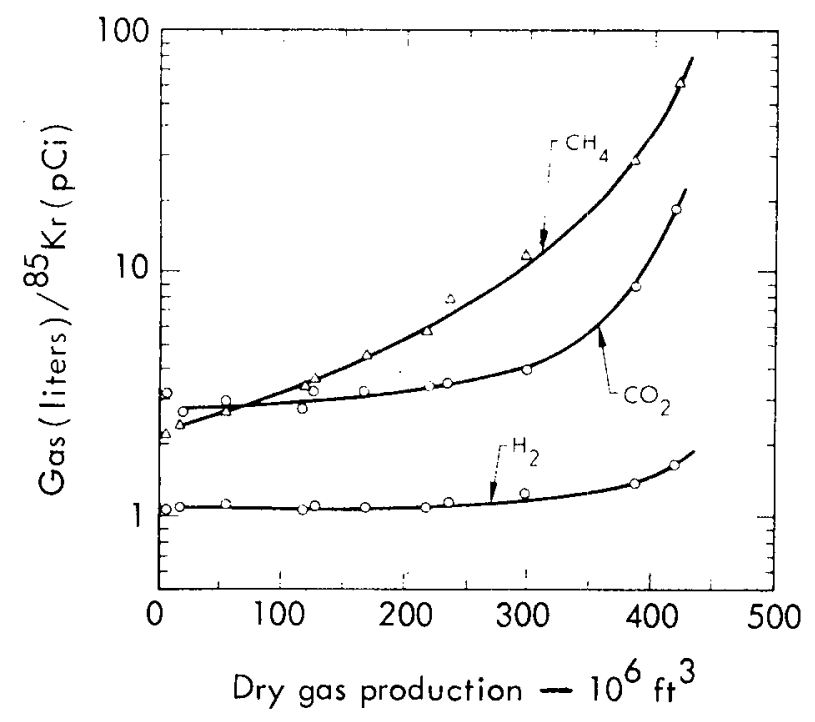

FIG. 17. Ratio of selected chimney gas components to ${ }^{85} \mathrm{Kr}$ during production testing at Project Rulison plotted as a function of dry gas produced (data points at $5 \times 10^{6} \mathrm{ft}^{3}$ are average of five samples collected during calibration flarings) - taken from Ref. 2.

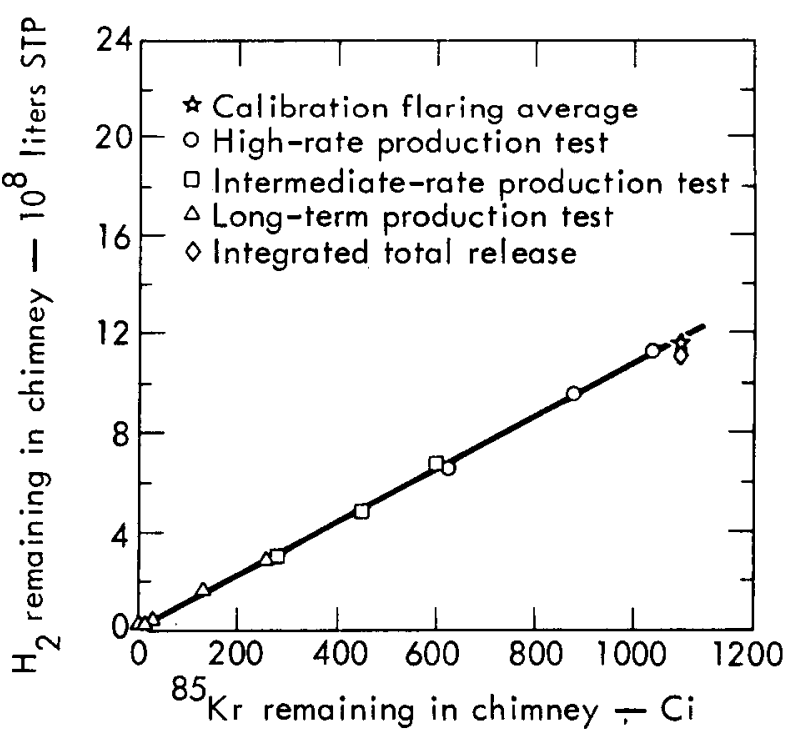

FIG. 18. Remaining $\mathrm{H}_{2}$ in Rulison chimney as a function of remaining ${ }^{85} \mathrm{Kr}$ (taken from Ref. 2). 


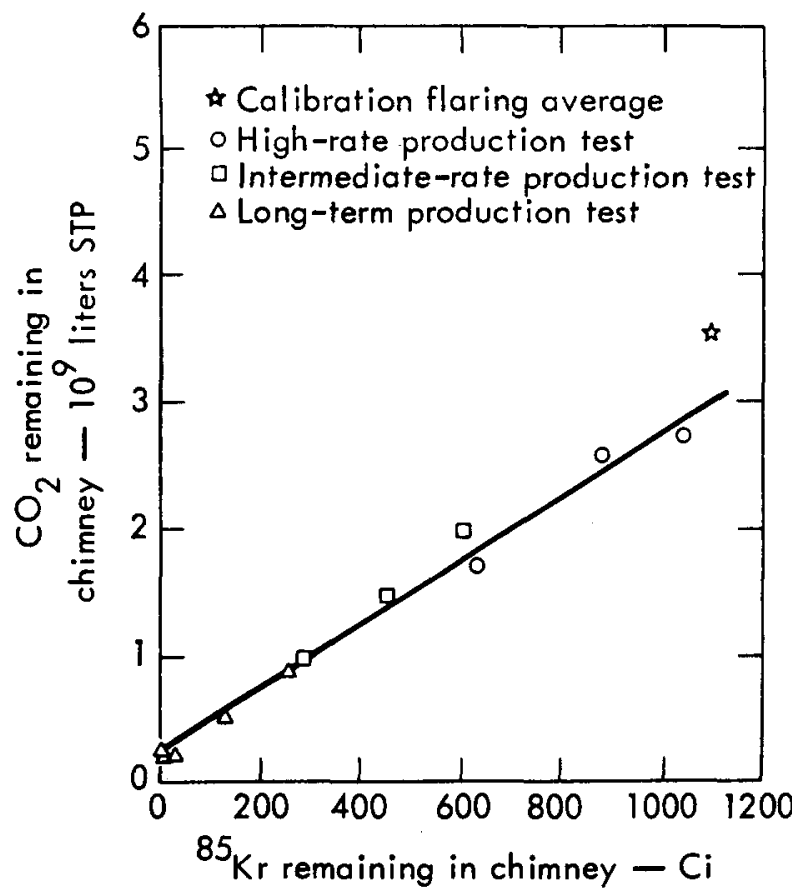

FIG. 19. Remaining $\mathrm{CO}_{2}$ in Rulison chimney as a function of remaining ${ }^{85} \mathrm{Kr}$ (taken from Ref. 2).

The following equations were obtained:

$$
\begin{array}{r}
\mathrm{H}_{2}\left[10^{9} \text { litres }(\mathrm{STP})\right]=(1.07 \pm 0.01) \times 10^{-3} \\
\times\left({ }^{85} \mathrm{Kr} \mathrm{Ci}\right)+(3.3 \pm 4.5) \times 10^{-3} \\
\left.\mathrm{CO}_{2}\left[10^{9} \text { litres (STP }\right)\right]=(2.49 \pm 0.12) \times 10^{-3} \\
\times\left({ }^{85} \mathrm{Kr} \mathrm{Ci}\right)+(0.245 \pm 0.082) .
\end{array}
$$

Accordingly, $(3.3 \pm 4.5) \times 10^{6}$ litres (STP) $\mathrm{H}_{2}$ and $(2.45 \pm 0.82) \times 10^{8}$ litres of $\mathrm{CO}_{2}$ are produced in excess of the gases initially mixed with ${ }^{85} \mathrm{Kr}$. This amount of $\mathrm{H}_{2}$ is only $(0.3 \pm 0.4) \%$ of the $1.18 \times 10^{9}$ litres of $\mathrm{H}_{2}$ present in the original chimney gas, and is not statistically different from zero.* The incremental amount of $\mathrm{CO}_{2}$ observed, $(2.45 \pm 0.82) \times 10^{8}$ litres (STP), is statistically different from zero, and represents $(8.2 \pm 2.7) \%$ of the total volume of $\mathrm{CO}_{2}\left(3.0 \times 10^{9}\right.$ litres) which was present before production testing of the Rulison chimney.

In order to investigate further the apparent addition of low specific activity $\mathrm{CO}_{2}$ to that $\mathrm{CO}_{2}$ already present in the chimney gas, Smith $^{2}$ determined how the remaining ${ }^{14} \mathrm{CO}_{2}$ in the chimney gas varied as a function of the remaining ${ }^{85} \mathrm{Kr}$. A regression analysis of these data indicated that all of the ${ }^{14} \mathrm{CO}_{2}$ produced was present in the chimney gas before the start of pro-

\footnotetext{
*Probability that this quantity is zero is about $25 \%$.
}

duction testing. That is, within statistical error, it was confirmed that the incremental $\mathrm{CO}_{2}$ that was produced during the production testing period contained no ${ }^{14} \mathrm{C}$.

Rio Blanco (Top chimney). Figure 20 presents the ratios of $\mathrm{H}_{2}, \mathrm{CO}_{2}$, and $\mathrm{CH}_{4}$ to ${ }^{85} \mathrm{Kr}$ plotted as a function of total dry gas production. Here again, the $\mathrm{CH}_{4}$-to- ${ }^{85} \mathrm{Kr}$ ratio rises rapidly as expected, due to dilution of the chimney gas by formation gas. The $\mathrm{CO}_{2}-$ to- ${ }^{85} \mathrm{Kr}$ ratio also increases significantly with total gas production, indicating that $\mathrm{CO}_{2}$ is being formed during the course of the production testing of the chimney. However, the $\mathrm{H}_{2}-\mathrm{to}^{-}{ }^{85} \mathrm{Kr}$ ratio actually appears to be dropping slightly at first before showing a moderate increase. It is not clear whether this effect is real or is due to experimental error. If it were real, it would imply that over part of the production period, there had been an influx of gas with a higher concentration of ${ }^{85} \mathrm{Kr}$ relative to $\mathrm{H}_{2}$ than that present in the chimney when production testing was first started: i.e., there would have to be a "reservoir" of gas having a low ratio of $\mathrm{H}_{2}$-to- ${ }^{85} \mathrm{Kr}$, which was out of direct contact with the chimney gas until production testing was started and the chimney pressure was significantly reduced. Presumably, this gas would be representative of an early stage* in the chimney gas history; possibly, the reservoir could be the cracked rock surrounding the chimney and cavity system into which the gas was forced by the high pressures (greater than formation pressure) within the chimney. After this reservoir was established, more $\mathrm{H}_{2}$ would have to be formed in the chimney region to increase the $\mathrm{H}_{2}$-to- ${ }^{85} \mathrm{Kr}$ ratio in the chimney gas.

In explaining the behavior of the $\mathrm{CO}_{2}$ in the upper Rio Blanco chimney, the specific activity data in Fig. 13a must be considered in addition to the information presented in Fig. 20. The increasing specific activity of the $\mathrm{CO}_{2}$ tends to support the gas reservoir concept, with the gas in the reservoir having a higher specific activity than that present in the chimney when production testing was started. Presumably, after the reservoir was filled with primordial chimney gas, the remaining $\mathrm{CO}_{2}$ (containing no ${ }^{14} \mathrm{C}$ ) was released as additional carbonate rock was decomposed by high-

*Note, however, that at early times in the Gasbuggy chimney (see Fig. 2), there was a relatively large volume fraction of $\mathrm{H}_{2}$ present in the gas. Thus, this "early stage" hypothesis could be valid only if (a) $\mathrm{H}_{2}$-rich gas did not exist at early times in the upper Rio Blanco chimney, or (b) the reservoir of low- $\mathrm{H}_{2}$ gas were formed some time after most of the $\mathrm{H}_{2}$ initially present in the chimney gas had reacted chemically with other substances. 


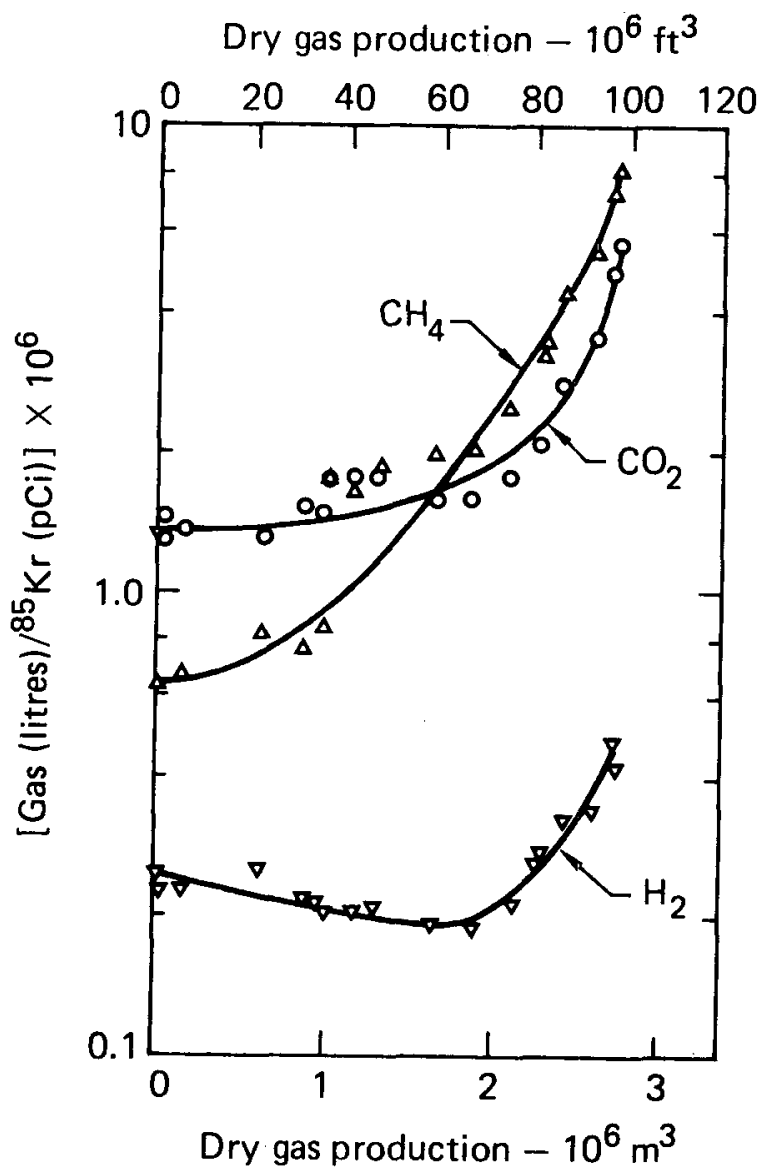

FIG. 20. Ratio of selected chimney gas components to ${ }^{85} \mathrm{Kr}$ during production testing at Project Rio Blanco (top chimney) plotted as a function of dry gas produced.

temperature reactions between carbonate and silicate minerals. As the pressure in the chimney was reduced during the course of production testing, the high specific activity $\mathrm{CO}_{2}$ entered the chimney and mixed with the chimney gas.*

Because this hypothesis requires ${ }^{85} \mathrm{Kr}$ to have been present in the reservoir, the low solubility of krypton in water tends to rule out the possibility that the reservoir effect was provided by primordial chimney gas dissolved in chimney water.

*If this effect can be detected from measurements of ${ }^{14} \mathrm{CO}_{2} / \mathrm{CO}_{2}$, then similar observations should result from determinations of the $\mathrm{HT} / \mathrm{H}_{2}$ ratio. However, if as previously noted. HT may either not be well-mixed at early times, or not in complete exchange equilibrium with other hydrogen-containing species in the gas, then it is not clear how the $\mathrm{HT} / \mathrm{H}_{2}$ ratio would be affected. In fact, it is possible that the $\mathrm{HT} / \mathrm{H}_{2}$ ratio would not change with increasing gas production, as is apparently the case here.
While the available data do not appear to be inconsistent with the foregoing suggested hypothesis, it is nct possible to present a conclusive proof, including the amounts of gas involved, a definite time sequence, etc.

If the reservoir hypothesis is correct, the treatment of data that relates the amounts of $\mathrm{H}_{2}$ and $\mathrm{CO}_{2}$ remaining in the chimney to the remaining ${ }^{85} \mathrm{Kr}$ could give anamolous results, since ${ }^{85} \mathrm{Kr}$ would also be added to the chimney gas during the course of production testing. However, if it is assumed that the incremental amount of ${ }^{85} \mathrm{Kr}$ is relatively small, then the error introduced into the calculations will be small. Consequently, the appropriate regression analyses were carried out on the data shown in Figs. 21 and 22. It was assumed that the total ${ }^{85} \mathrm{Kr}$ present in the chimney gas initially is $775 \pm 80 \mathrm{Ci}^{14}$ The following equations were obtained:

$$
\begin{aligned}
& \mathrm{H}_{2}\left[10^{9} \text { litres }(\mathrm{STP})\right]=(2.35 \pm 0.07) \times 10^{-4} \\
& \times\left({ }^{85} \mathrm{Kr} \mathrm{Ci}\right)-(5.17 \pm 3.10) \times 10^{-3} \\
& \mathrm{CO}_{2}\left[10^{9} \text { litres }(\mathrm{STP})\right]=(1.29 \pm 0.05) \times 10^{-3} \\
& \times\left({ }^{85} \mathrm{Kr} \mathrm{Ci}\right)+(7.42 \pm 2.50) \times 10^{-2} .
\end{aligned}
$$

On the basis of this statistical treatment, there is only a $5 \%$ probability (approx.) that any $\mathrm{H}_{2}$ is produced in excess of that mixed with ${ }^{85} \mathrm{Kr}$. However, some fraction $(7.4 \pm 2.5) \times 10^{7}$ litres of $\mathrm{CO}_{2}$ in excess of that

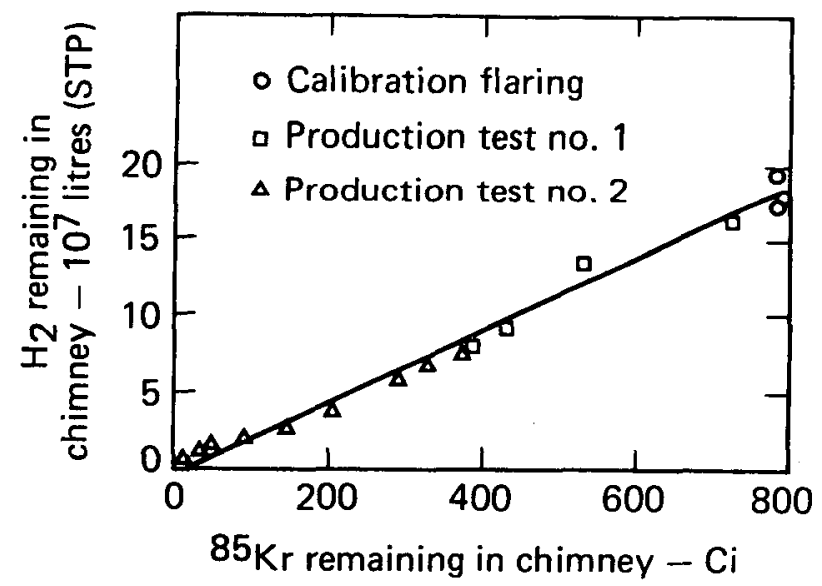

FIG. 21. Remaining $\mathrm{H}_{2}$ in Rio Blanco top chimney as a function of remaining ${ }^{85} \mathbf{K r}$.

* When the residual ${ }^{14} \mathrm{CO}_{2}$ in the chimney is plotted against the ${ }^{85} \mathrm{Kr}$ remaining in the chimney, it appears that some fraction of the ${ }^{14} \mathrm{CC}_{2}$ was introduced into the chimney during the course of production testing; i.e., the $\mathrm{CO}_{2}$ formed or released during this time contained some ${ }^{14} \mathrm{CO}_{2}$. Unfortunately, the data are not sufficient to obtain a quantitative result. 


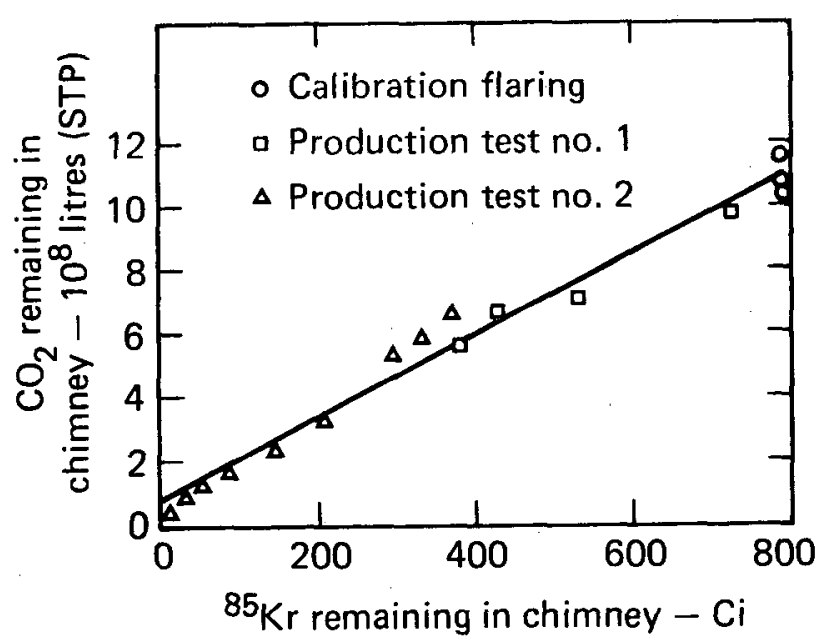

FIG. 22. Remaining $\mathrm{CO}_{2}$ in Rio Blanco top chimney as a function of remaining ${ }^{85} \mathrm{Kr}$.

present in the chimney at the beginning of production testing was formed during the course of the test period.* This amount of $\mathrm{CO}_{2}$ is $(6.8 \pm 2.3) \%$ of the $1.10 \times 10^{9}$ litres of $\mathrm{CO}_{2}$ that was present before production testing of the top Rio Blanco chimney.

Rio Blanco (Bottom chimney). The ratios of $\mathrm{H}_{2}$, $\mathrm{CO}_{2}$, and $\mathrm{CH}_{4}$ to ${ }^{85} \mathrm{Kr}$ shown in Fig, 23 are plotted as a function of total dry gas production. Due to the limited extent of the production testing, it is possible to detect only trends; however, it appears that the behavior of the $\mathrm{H}_{2}, \mathrm{CO}_{2}$, and $\mathrm{CH}_{4}$ is similar to that observed on the Rulison experiment. Unlike the observed initial decrease of the $\mathrm{H}_{2}$-to- ${ }^{85} \mathrm{Kr}$ ratio seen for the Rio Blanco top chimney, this ratio appears to be increasing slightly as a function of total gas production. Thus, it appears that some small amount of $\mathrm{H}_{2}$ in addition to that present in the chimney gas at the start of production could be entering the chimney during the production test period; the same is true for $\mathrm{CO}_{2}$, with the exception that the incremental fractional increase seems to be larger than it is for $\mathrm{H}_{2}$.

With reference to Fig. 13b, it can be seen that this apparent addition of incremental amounts of $\mathrm{H}_{2}$ and $\mathrm{CO}_{2}$ to the chimney gas is not accompanied by any change in the specific activities of these species. This would indicate that the source of the incoming $\mathrm{H}_{2}$ and $\mathrm{CO}_{2}$ could be the ebullition of dissolved gas from water in the chimney, as was also postulated in the case of Gasbuggy. However, it should be pointed out that the effects noted for the Rio Blanco bottom chimney are relatively small, and could be due to experimental error.
In order to analyse further the available data, regression analyses were run using the information displayed in Figs. 24 and 25, and assuming that the total ${ }^{85} \mathrm{Kr}$ in the bottom chimney prior to the production testing was $700 \pm 20 \mathrm{Ci}^{4}{ }^{4}$ The following equations were obtained:

$$
\begin{array}{r}
\mathrm{H}_{2}\left[10^{9} \text { litres }(\mathrm{STP})\right]=(3.42 \pm 0.16) \times 10^{-4} \\
\times\left({ }^{85} \mathrm{Kr} \mathrm{Ci}\right)+(3.73 \pm 0.97) \times 10^{-2} \\
\mathrm{CO}_{2}\left[10^{9} \text { litres }(\mathrm{STP})\right]=(9.58 \pm 2.29) \times 10^{-4} \\
\times\left({ }^{85} \mathrm{Kr} \mathrm{Ci}\right)+(0.30 \pm 0.14) .
\end{array}
$$

Thus, an incremental volume of $(3.73 \pm 0.97) \times 10^{7}$ litres of $\mathrm{H}_{2}$ is released during production testing, which amount is about $(13 \pm 4) \%$ of the $2.77 \times 10^{8}$ litres of $\mathrm{H}_{2}$ present at the start of production testing. Likewise, $(3.0 \pm 1.4) \times 10^{8}$ litres of $\mathrm{CO}_{2}$ is released during production testing, or some $(31 \pm 15) \%$ of the $9.69 \times 10^{8}$ litres of $\mathrm{CO}_{2}$ present in the chimney gas initially.

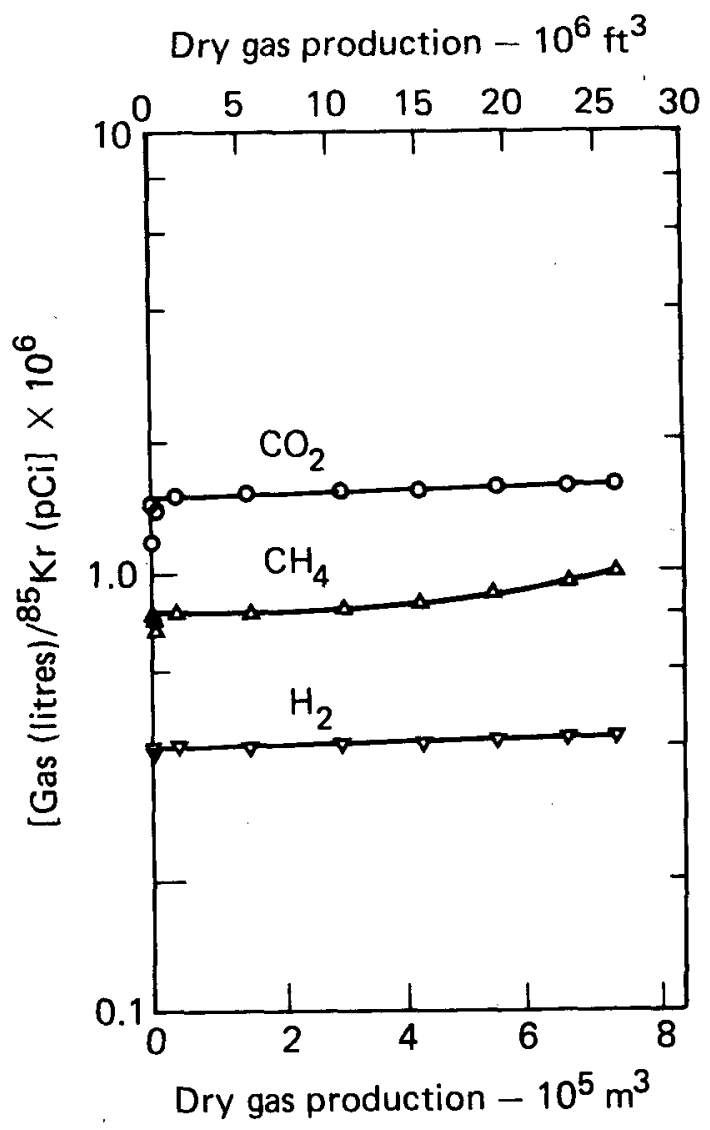

FIG. 23. Ratio of selected chimney gas components to ${ }^{85} \mathrm{Kr}$ during production testing at Rio Blanco (bottom chimney) plotted as a function of dry gas produced. 


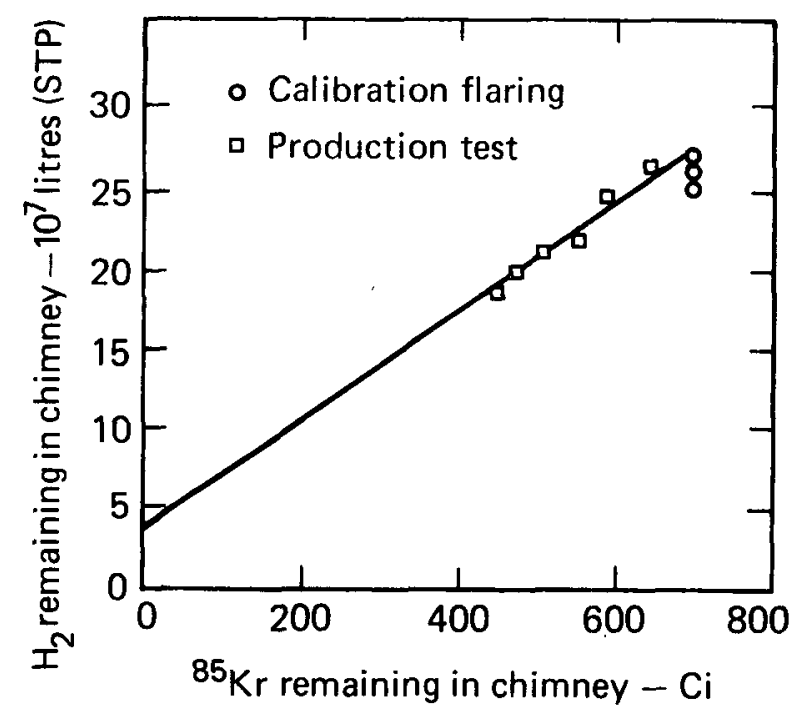

FIG. 24. Remaining $\mathrm{H}_{2}$ in bottom Rio Blanco chimney as a function of remaining ${ }^{85} \mathrm{Kr}$.

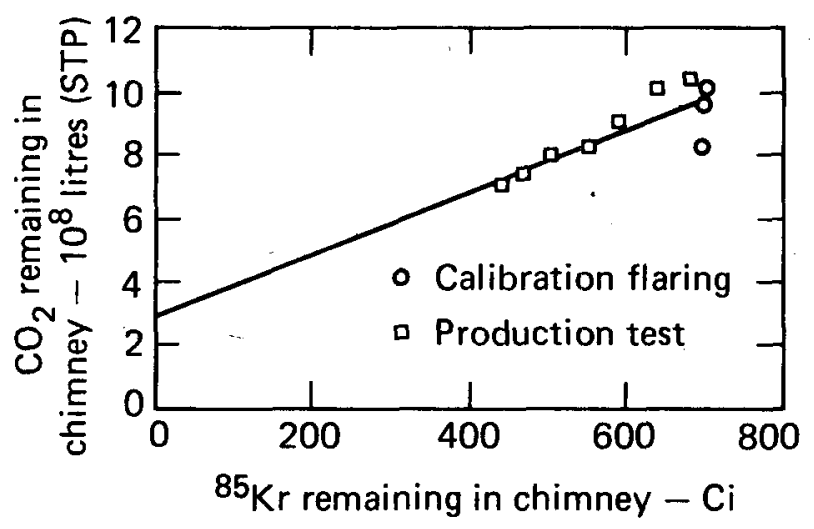

FIG. 25. Remaining $\mathrm{CO}_{2}$ in bottom Rio Blanco chimney as a function of remaining ${ }^{85} \mathbf{K r}$.
Summary. In addition to the $\mathrm{H}_{2}$ and $\mathrm{CO}_{2}$ present in the chimney gas of the three gas stimulation experiments before production testing is started, additional amounts of these gases appear to be released into the chimney during the course of the production testing. It appears that several different mechanisms could be responsible for this observed effect, as noted above.

The estimated amounts of $\mathrm{H}_{2}$ and $\mathrm{CO}_{2}$ present in the initial chimney gas, as well as the additional amounts released into the chimney during the production testing period, are summarized in Table 9.

\section{TOTAL AMOUNTS OF PRODUCT GASES PRESENT PRIOR TO PRODUCTION TESTING}

A convenient method for determining the total amount of a gaseous material present in a chimney involves the measurement of the ratio of the concentration of this material in the chimney gas to the concentration of ${ }^{85} \mathrm{Kr}$ in the gas (for more details, see Ref. 2). Multiplying this ratio by the total amount of ${ }^{85} \mathrm{Kr}$ present gives the total amount of the gaseous material in the chimney gas:

$$
\text { Total } \mathrm{x}=\frac{[\mathrm{x}]}{\left[{ }^{85} \mathrm{Kr}\right]} \times \text { total }{ }^{85} \mathrm{Kr} \text {, }
$$

where $[\mathrm{x}]$ and $\left[{ }^{85} \mathrm{Kr}\right]$ are measured concentrations of these species in a gas sample. The total amount of ${ }^{85} \mathrm{Kr}$ present in the cavity can be determined by the fission yield of the nuclear explosive, or, where this is only approximately known, by integrating the total amount of ${ }^{85} \mathrm{Kr}$ released during production testing (but only when essentially all of the chimney gases are

TABLE 9. Initial and incremental amounts of $\mathrm{H}_{2}$ and $\mathrm{CO}_{2}$ present in gas from nuclearly stimulated wells.

\begin{tabular}{|c|c|c|c|c|}
\hline \multirow{3}{*}{$\begin{array}{l}\text { Chemical } \\
\text { species }\end{array}$} & \multicolumn{4}{|c|}{ Amounts present in gas $-10^{9}$ litres (STP) } \\
\hline & \multirow[b]{2}{*}{ Gasbuggy } & \multirow[b]{2}{*}{ Rulison } & \multicolumn{2}{|c|}{ Rio Blanco } \\
\hline & & & Top chimney & Bottom chimney \\
\hline \multicolumn{5}{|l|}{$\mathbf{H}_{2}$} \\
\hline $\begin{array}{l}\text { Original } \\
\text { Incremental }\end{array}$ & $\begin{array}{l}0.442 \pm 0.028 \\
0.020 \pm 0.012\end{array}$ & $\begin{array}{l}1.18 \pm 0.01 \\
0.003 \pm 0.005\end{array}$ & $\begin{array}{c}0.182 \pm 0.006 \\
-\end{array}$ & $\begin{array}{l}0.277 \pm 0.015 \\
0.037 \pm 0.010\end{array}$ \\
\hline Total & $0.462 \pm 0.030$ & $1.18 \pm 0.01$ & $0.182 \pm 0.006$ & $0.314 \pm 0.018$ \\
\hline \multicolumn{5}{|l|}{$\mathrm{CO}_{2}$} \\
\hline $\begin{array}{l}\text { Original } \\
\text { Incremental }\end{array}$ & $\begin{array}{l}1.24 \pm 0.08 \\
0.09 \pm 0.04\end{array}$ & $\begin{array}{l}2.98 \pm 0.16 \\
0.245 \pm 0.08\end{array}$ & $\begin{array}{l}1.10 \pm 0.05 \\
0.074 \pm 0.05\end{array}$ & $\begin{array}{l}0.969 \pm 0.214 \\
0.298 \pm 0.142\end{array}$ \\
\hline Total & $1.33 \pm 0.08$ & $3.23 \pm 0.18$ & $1.17 \pm 0.05$ & $1.27 \pm 0.26$ \\
\hline
\end{tabular}


produced). In the case of the Rio Blanco bottom chimney, where all of the gas was not released, an estimate of the amount of ${ }^{85} \mathrm{Kr}$ in the chimney was made by ratioing ${ }^{85} \mathrm{Kr}$ concentrations to the concentration of a noble gas tracer present in the gas.

The ${ }^{85} \mathrm{Kr}$ represents an ideal substance to use as a standard, because it is easily detectable, is chemically inert, and presumably is completely mixed with the chimney gas shortly after chimney formation. The ratio $[\mathrm{x}] /\left[{ }^{85} \mathrm{Kr}\right]$ (see above) can be expected to remain constant during the course of production testing only for those species that do not undergo physical or chemical changes during the course of the testing period; clearly, the ratio would also be affected if additional quantities of " $\mathrm{x}$ " were added during production. For example, in the case of $\mathrm{CH}_{4}$, the ratio would be expected to remain essentially constant only until a significant amount of formation gas began to diffuse into the chimney.

Total amounts of individual components of the chimney gas also can be determined in the same manner as is the ${ }^{85} \mathrm{Kr}$ : by integrating the total release. This method is applicable only when essentially all of the gas originally in the chimney is produced.

Gasbuggy. Table 10 gives the calculated totals for the gaseous species present in the Gasbuggy chimney at the start of production testing, based on the data given in Ref. 1. In the case of the $\mathrm{CO}_{2}$, the integrated

TABLE 10. Totals of gaseous species - Project Gasbuggy. ${ }^{\text {a }}$

\begin{tabular}{|c|c|c|c|c|c|c|}
\hline \multirow[b]{3}{*}{$\begin{array}{c}\text { Major } \\
\text { components }\end{array}$} & \multicolumn{6}{|c|}{ Total volume of major component species produced $-\times 10^{9}$ litres (STP) } \\
\hline & \multirow[b]{2}{*}{$\begin{array}{c}\text { Calibration } \\
\text { flaring } \\
\text { average }^{b}\end{array}$} & \multicolumn{3}{|c|}{ Production testing } & \multicolumn{2}{|c|}{ Preferred values } \\
\hline & & $\begin{array}{l}1.4 \times 10^{5} \mathrm{~m}^{3} / \mathrm{day} \\
\text { production test } \\
(\text { samples } 20-29)\end{array}$ & $\begin{array}{c}\text { Regression } \\
\text { analysis }\end{array}$ & $\begin{array}{l}\text { Integrated } \\
\text { release }^{d}\end{array}$ & $\begin{array}{l}\text { Totals } \\
\text { initially } \\
\text { present }\end{array}$ & $\begin{array}{c}\text { Based on } \\
\text { average of } \\
\text { columns }\end{array}$ \\
\hline $\mathrm{CO}_{2}$ & $1.09 \pm 0.08$ & $0.99 \pm 0.16$ & $1.24 \pm 0.10$ & $1.43 \pm 0.14$ & $1.11 \pm 0.11$ & $1,2,3$ \\
\hline $\mathbf{H}_{2}$ & $0.48 \pm 0.06$ & $0.32 \pm 0.06$ & $0.44 \pm 0.04$ & $0.46 \pm 0.05$ & $0.42 \pm 0.07$ & $1,2,3,4$ \\
\hline $\mathrm{CH}_{4}$ & $1.19 \pm 0.10$ & $1.40 \pm 0.09$ & - & - & $1.30 \pm 0.10$ & 1,2 \\
\hline $\mathrm{C}_{2} \mathrm{H}_{6}$ & $0.119 \pm 0.012$ & $0.145 \pm 0.011$ & - & - & $0.132 \pm 0.012$ & 1,2 \\
\hline $\mathrm{C}_{3} \mathrm{H}_{8}$ & $0.035 \pm 0.004$ & $0.038 \pm 0.004$ & - & - & $0.037 \pm 0.004$ & 1,2 \\
\hline TOTAL & $2.91 \pm 0.14$ & $2.89 \pm 0.19$ & 一 & - & $3.00 \pm 0.17$ & \\
\hline $\begin{array}{c}\text { Radioactive } \\
\text { species }\end{array}$ & \multicolumn{6}{|c|}{ Total amounts of radioactive species produced - curies at $\mathrm{T}_{0}$} \\
\hline \multicolumn{7}{|l|}{ Tritium as: } \\
\hline HT & $441 \pm 146$ & $146 \pm 29$ & - & $206 \pm 21$ & $176 \pm 38$ & 2,4 \\
\hline $\mathrm{CH}_{3} \mathrm{~T}$ & $1420 \pm 110$ & $1420 \pm 220$ & - & $1720 \pm 170$ & $1520 \pm 170$ & $1,2,4$ \\
\hline $\mathrm{C}_{2} \mathrm{H}_{5} \mathrm{~T}$ & $249 \pm 18$ & $251 \pm 40$ & - & $297 \pm 30$ & $266 \pm 30$ & $1,2,4$ \\
\hline $\mathrm{C}_{3} \mathrm{H}_{7} \mathrm{~T}$ & $66 \pm 33$ & $44 \pm 4$ & - & $45 \pm 4$ & $44 \pm 4$ & 2,4 \\
\hline $\begin{array}{l}\text { Total Tritium } \\
37_{\mathrm{Ar}} \times 10^{-4}\end{array}$ & $2180 \pm 190$ & $1860 \pm 220$ & & $2260 \pm 170$ & $\begin{array}{c}2010 \pm 177 \\
1.3^{e}\end{array}$ & \\
\hline${ }^{39} \mathrm{Ar}$ & & & & & $0.25^{\mathrm{e}}$ & \\
\hline${ }^{14} \mathrm{C}$ as ${ }^{14} \mathrm{CO}_{2}$ & $6.08 \pm 1.51$ & $6.74 \pm 0.67$ & - & $7.38 \pm 0.74$ & $6.73 \pm 0.80$ & $1,2,4$ \\
\hline as ${ }^{14} \mathrm{CH}_{4}$ & $1.11 \pm 0.30$ & - & & $3.54 \pm 0.35$ & $3.54 \pm 0.35$ & 4 \\
\hline Total ${ }^{14} \mathrm{C}$ & $7.19 \pm 1.54$ & & - & $10.92 \pm 0.82$ & $10.27 \pm 0.90$ & \\
\hline
\end{tabular}

andicated uncertainties are one standard deviation of the mean.

${ }^{b}$ Based on $370 \mathrm{Ci}{ }^{85} \mathrm{Kr}$ and assuming uniform mixing.

Calues are the $370 \mathrm{Ci}{ }^{85} \mathrm{Kr}$ intercept of the weighted least-squares fit to the total gas remaining in the chimney as a function of the total

${ }^{85} \mathrm{Kr}$ remaining. Note that the amounts of radioactive gases in the chimney were not calculated by this method, since Ref. 2 indicates that the results as calculated by this procedure agree well with those found using the other methods employed in this analysis.

dntegrated amount released during all production. Assumes no residual in chimney; based on LLL experimental results given in Ref. I. An arbitrary $\pm 10 \%$ uncertainty has been assumed.

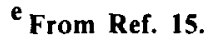


release value is higher than the other estimates, presumably due to the late time formation of additional $\mathrm{CO}_{2}$ in the vicinity of the original detonation point (as discussed above). From an examination of the data for $\mathrm{HT}$, the high production values calculated from the production data could indicate either incomplete mixing of the $\mathrm{H}_{2}$ in the chimney gas prior to production testing or failure to attain complete exchange with other tritium-containing substances.

The total amount of tritium present in the dry gas $(2010 \mathrm{Ci}$ ) is about $5 \%$ of the amount of $40,000 \mathrm{Ci}$ of residual tritium calculated to be present following the Gasbuggy detonation (Ref. 15).

Rulison. A summary of Rulison results has been taken from Ref. 2 and is presented as Table 11. It can be seen that some of the totals obtained from the calibration flaring samples disagree to some extent with the values obtained using production test data. The effect here seems to be more pronounced than it was with the Gasbuggy data; it is possible that the cause is the same; i.e., that the chimney gases may not have been well-mixed prior to production testing. Again, the integrated release of $\mathrm{CO}_{2}$ is appreciably above the other values, presumably due to the late-time generation of $\mathrm{CO}_{2}$ (during the course of the production testing).

A total of about $1300 \mathrm{Ci}$ of gaseous tritium was present in the Rulison chimney gas, or approximately $13 \%$ of the $10,000 \mathrm{Ci}$ of this nuclide that was predicted to be present following the detonation of the Rulison explosive (Ref. 2).

Fio Blanco (Top chimney). Totals for the gaseous specie:s in the Rio Blanco top chimney are listed in Table 12. Once again, the integrated release of $\mathrm{CO}_{2}$ is higher than the other values, due to the (presumed)

TABLE 11. Totals of gaseous species - Project Rulison. ${ }^{a}$

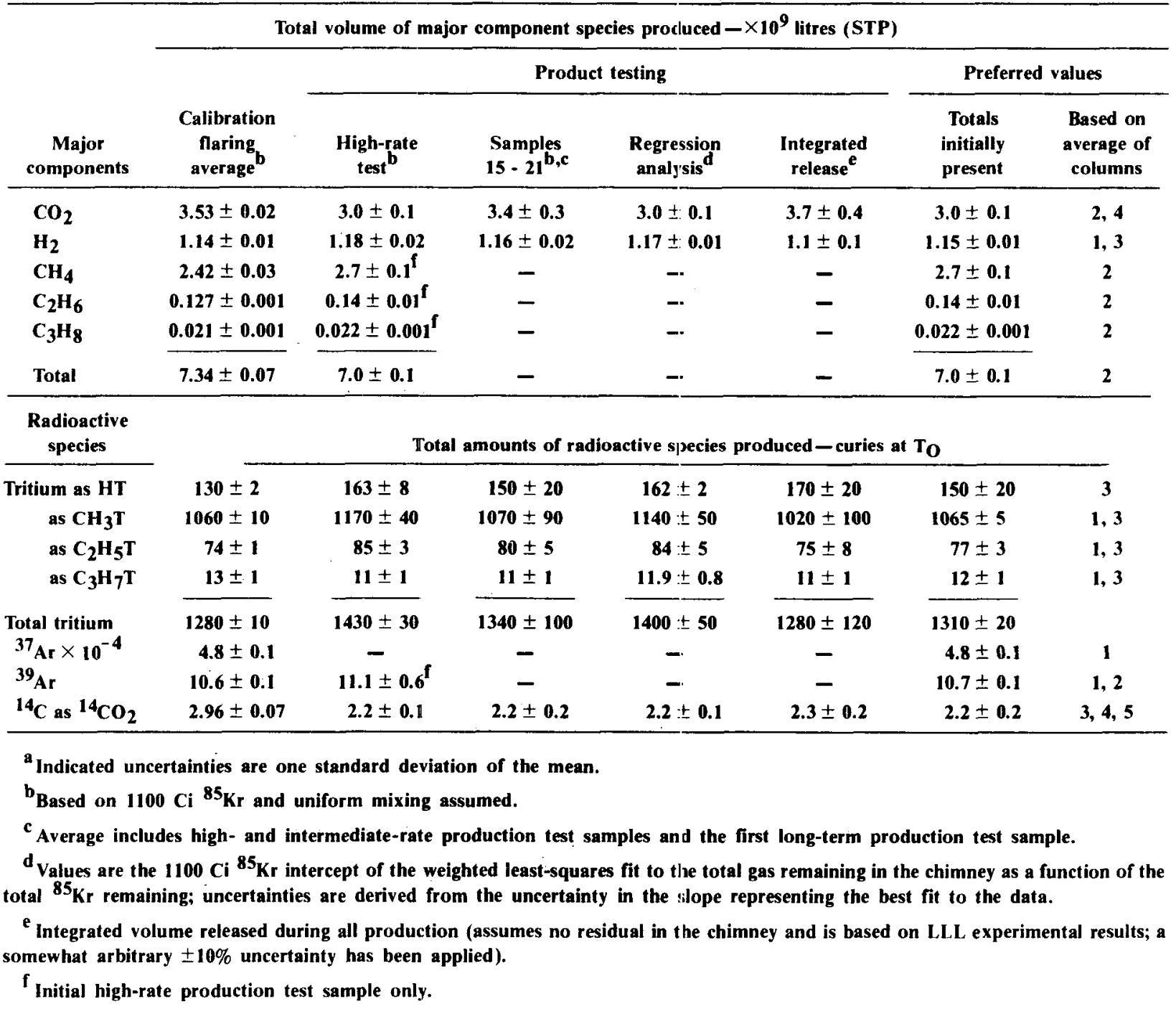


late-time generation of $\mathrm{CO}_{2}$. Also, results from the calibration flaring gas samples are not consistent with those from production testing samples insofar as the calculated amount of HT present is concerned. Finally, the discrepancy between the values for total ${ }^{14} \mathrm{CO}_{2}$ as determined from an integration of the production data and from data obtained on calibration and first production test samples is the result of apparent addition of high specific activity ${ }^{14} \mathrm{CO}_{2}$ to the chimney gas between the first and second production tests. This anomalous observation was discussed above.

The total amount of tritium produced with the dry gas was about $53 \mathrm{Ci}$. It was calculated that each Rio Blanco explosive would inject $<1000 \mathrm{Ci}$ of tritium ${ }^{9}$ into the post-detonation (cavity and chimney) environment; results show that no less than about $5 \%$ of this tritium was present in the dry gas.
Rio Blanco (Bottom chimney). Table 13 presents the totals for the gaseous species contained in the Rio Blanco bottom chimney. As indicated in the table, it was not possible to obtain integrated release values, because only about a third of the chimney gas was released. Because of the short production test, it was not possible to determine whether the ${ }^{14} \mathrm{CO}_{2}$ behaved like it did in the top chimney.

The total amount of tritium present in the dry chimney gas was about $57 \mathrm{Ci}$, indicating that no less than about $6 \%$ of the residual tritium from the bottom explosion was chemically incorporated into the gas.

Summary. Table 14 gives an overview of the total gas production from the three U.S. nuclear gas stimulation experiments, based on data from samples analyzed at LLL. Note that Gasbuggy had the largest

TABLE 12. Totals of gaseous species - top chimney, Project Rio Blanco. ${ }^{a}$

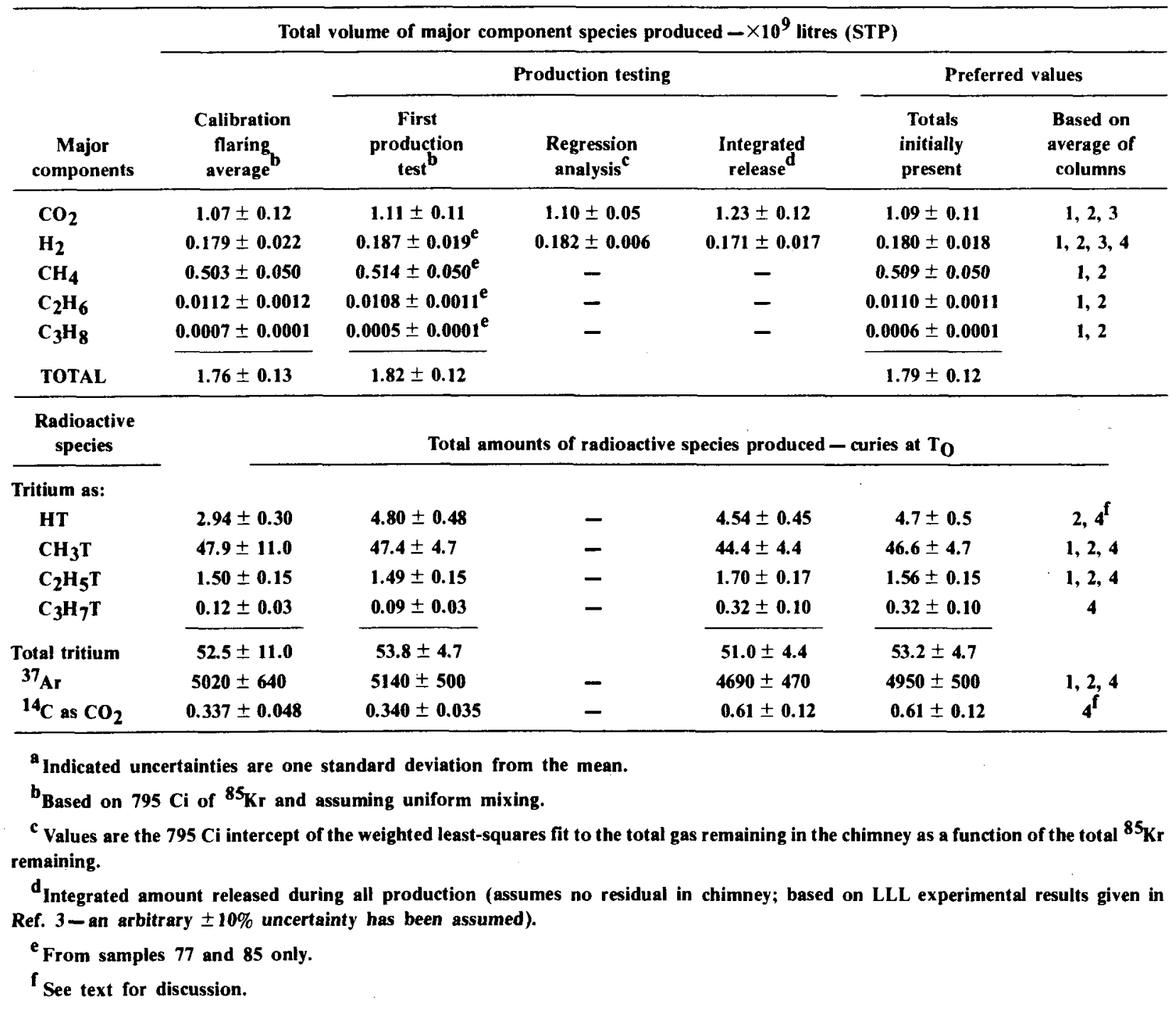


TABLE 13. Totals of gaseous species - bottom chimney, Project Rio Blanco. ${ }^{\mathrm{a}}$

\begin{tabular}{|c|c|c|c|c|}
\hline \multirow[b]{3}{*}{$\begin{array}{c}\text { Major } \\
\text { components }\end{array}$} & \multicolumn{4}{|c|}{ Total volume of major component species produced $-\times 10^{9}$ litres (STP) } \\
\hline & \multirow[b]{2}{*}{$\begin{array}{c}\text { Calibration } \\
\text { flaring } \\
\text { average }\end{array}$} & \multicolumn{2}{|c|}{ Production testing } & \multirow[b]{2}{*}{ Totals initially present ${ }^{e}$} \\
\hline & & $\begin{array}{c}\text { First } \\
\text { production } \\
\text { test }^{c}\end{array}$ & $\begin{array}{l}\text { Regression } \\
\text { analysis }\end{array}$ & \\
\hline $\mathrm{CO}_{2}$ & $0.932 \pm 0.088$ & $1.01 \pm 0.05^{f}$ & $0.97 \pm 0.21$ & $0.97 \pm 0.10$ \\
\hline $\mathbf{H}_{2}$ & $0.272 \pm 0.013$ & $0.272 \pm 0.017^{f}$ & $0.28 \pm 0.01$ & $0.27 \pm 0.01$ \\
\hline $\mathrm{CH}_{4}$ & $0.542 \pm 0.020$ & $0.495 \pm 0.038^{f}$ & - & $0.52 \pm 0.03$ \\
\hline $\mathrm{C}_{2} \mathrm{H}_{6}$ & $0.036 \pm 0.001$ & $0.033 \pm 0.002^{f}$ & - & $0.035 \pm 0.002$ \\
\hline $\mathrm{C}_{3} \mathrm{H}_{8}$ & $0.005 \pm 0.001$ & $0.005 \pm 0.001^{f}$ & - & $0.005 \pm 0.001$ \\
\hline TOTAL & $1.79 \pm 0.09$ & $1.82 \pm 0.07$ & & $1.80 \pm 0.10$ \\
\hline $\begin{array}{l}\text { Radioactive } \\
\text { species }\end{array}$ & \multicolumn{4}{|c|}{ Total amounts of radioactive species produced - curies at $T_{O}$} \\
\hline \multicolumn{5}{|l|}{ Tritium as: } \\
\hline HT & $8.63 \pm 0.28$ & $7.64 \pm 1.30$ & - & $7.84 \pm 1.24$ \\
\hline $\mathrm{CH}_{3} \mathrm{~T}$ & $52.3 \pm 1.7$ & $42.1 \pm 8.2$ & - & $44.2 \pm 9.0$ \\
\hline $\mathrm{C}_{2} \mathrm{H}_{5} \mathrm{~T}$ & $5.61 \pm 0.19$ & $4.78 \pm 1.27$ & - & $4.94 \pm 1.18$ \\
\hline $\mathrm{C}_{3} \mathrm{H}_{7} \mathrm{~T}$ & $0.42 \pm 0.01$ & $0.36 \pm 0.05$ & - & $0.37 \pm 0.05$ \\
\hline Total tritium & $67.0 \pm 1.7$ & $54.9 \pm 8.4$ & & $57.4 \pm 9.2$ \\
\hline${ }^{39} \mathrm{Ar}$ & $0.55 \pm 0.02$ & $0.44 \pm 0.09$ & - & $0.46 \pm 0.09$ \\
\hline${ }^{14} \mathrm{C}$ as ${ }^{14} \mathrm{CO}_{2}$ & $0.27 \pm 0.01$ & $0.29 \pm 0.07$ & - & $0.29 \pm 0.06$ \\
\hline
\end{tabular}

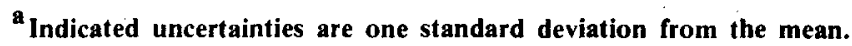

${ }^{b}$ Integrated release quantities were not computed because the drawdown was terminated before all of the chimney gas had been released.

c Based on $700 \mathrm{Ci}$ of ${ }^{85} \mathrm{Kr}$ and assuming uniform mixing.

${ }^{\mathrm{d}}$ Values are the $700 \mathrm{Ci}$ intercept of the weighted least-squares fit to the total gas remaining in the chimney as a function of the total ${ }^{85} \mathrm{Kr}$ remaining.

e All data averaged.

from samples 170 and 171 only.
}

ratio of hydrocarbons to explosion-produced gases of the three experiments, while Rio Blanco had the smallest. Also, the ratio of the heavier alkanes to methane was larger for Gasbuggy than for either of the other two events. In this regard, note the difference in the hydrocarbon composition of the gas in the two Rio Blanco chimneys. In summary, the differences in the gas compositions and total amount of gas present in the four chimneys considered in this report can be attributed to a combination of factors: different explosive yields, different formation pressures, different amounts of nonorganic carbon in the rocks surrounding the detonations, and different cavity temperatures (which in turn affected the partial pressure of the water vapor in the chimneys).

With regard to the radioactivity present in the gas, one of the principal effects is the reduction in the tritium present in the gas phase, as accomplished by the development of the advanced Diamond explo- sive design. Interestingly, it is clear that the production of activation products (including ${ }^{37} \mathrm{Ar},{ }^{39} \mathrm{Ar}$, and ${ }^{14} \mathrm{C}$ ) was generally much lower in the Rio Blanco experiment than in the other two. While this decrease may have been due in part to lower amounts of calcium, potassium, and nitrogen in the detonation environment, a reduction in the total number of neutrons emergent from the explosive may have contributed to this decrease as well.

Note that the amount of ${ }^{14} \mathrm{C}$ in the Rio Blanco bottom chimney appears to be lower than the amount in the top chimney. This difference may be due to insufficient data from the bottom chimney; for the top chimney, the ${ }^{14} \mathrm{CO}_{2}$ content of the gas released during the second production test was significantly greater than that of the gas from the first test. The specific activity of ${ }^{14} \mathrm{CO}_{2}$ in the gas from the calibration flaring and first production test is similar for both chimneys. 
Table 14. Summary table of gaseous species found in chimneys of gas stimulation experiments.

\begin{tabular}{|c|c|c|c|c|}
\hline \multirow{3}{*}{$\begin{array}{c}\text { Major } \\
\text { components }\end{array}$} & \multicolumn{4}{|c|}{ Total volume of major component species produced $-\times 10^{9}$ litres (STP) } \\
\hline & \multirow[b]{2}{*}{ Gasbuggy } & \multirow[b]{2}{*}{ Rulison } & \multicolumn{2}{|c|}{ Rio Blanco } \\
\hline & & & Top chimney & Bottom chimney \\
\hline $\mathrm{CO}_{2}$ & $1.11 \pm 0.11$ & $3.0 \pm 0.1$ & $1.09 \pm 0.11$ & $0.97 \pm 0.10$ \\
\hline $\mathbf{H}_{2}$ & $0.42 \pm 0.07$ & $1.15 \pm 0.01$ & $0.18 \pm 0.02$ & $0.27 \pm 0.01$ \\
\hline $\mathrm{CH}_{4}$ & $1.30 \pm 0.10$ & $2.7 \pm 0.1$ & $0.51 \pm 0.05$ & $0.52 \pm 0.03$ \\
\hline $\mathrm{C}_{2} \mathrm{H}_{6}$ & $0.13 \pm 0.01$ & $0.14 \pm 0.01$ & $0.011 \pm 0.001$ & $0.035 \pm 0.002$ \\
\hline $\mathrm{C}_{3} \mathrm{H}_{8}$ & $0.037 \pm 0.004$ & $0.022 \pm 0.001$ & $0.0006 \pm 0.0001$ & $0.005 \pm 0.001$ \\
\hline TOTAL & $3.0 \pm 0.2$ & $7.0 \pm 0.1$ & $1.79 \pm 0.12$ & $1.80 \pm 0.10$ \\
\hline $\begin{array}{l}\text { Radioactive } \\
\text { species }\end{array}$ & \multicolumn{4}{|c|}{ Total amounts of radioactive species produced - curies at $T_{0}$} \\
\hline \multicolumn{5}{|l|}{ Tritium as: } \\
\hline HT & $176 \pm 38$ & $150 \pm 20$ & $4.7 \pm 0.5$ & $7.8 \pm 1.2$ \\
\hline $\mathrm{CH}_{3} \mathrm{~T}$ & $1520 \pm 170$ & $1065 \pm 5$ & $46.6 \pm 4.7$ & $44.2 \pm 9.0$ \\
\hline $\mathrm{C}_{2} \mathrm{H}_{5} \mathrm{~T}$ & $266 \pm 30$ & $77 \pm 3$ & $1.56 \pm 0.15$ & $4.94 \pm 1.18$ \\
\hline $\mathrm{C}_{3} \mathrm{H}_{7} \mathrm{~T}$ & $44 \pm 4$ & $12 \pm 1$ & $0.32 \pm 0.10$ & $0.37 \pm 0.05$ \\
\hline Total tritium & $2010 \pm 177$ & $1310 \pm 20$ & $53.2 \pm 4.7$ & $57.4 \pm 9.2$ \\
\hline${ }^{37} \mathrm{Ar}$ & 13,000 & $48,000 \pm 1000$ & $4,950 \pm 500$ & $-\mathbf{a}$ \\
\hline${ }^{39} \mathrm{Ar}$ & 0.25 & $10.7 \pm 0.1$ & $-\mathbf{b}$ & $0.46 \pm 0.09$ \\
\hline${ }^{14} \mathrm{C}$ as ${ }^{14} \mathrm{CO}_{2}$ & $6.7 \pm 0.8$ & $2.2 \pm 0.2$ & $0.61 \pm 0.12$ & $0.29 \pm 0.06$ \\
\hline as ${ }^{14} \mathrm{CH}_{4}$ & $3.5 \pm 0.4$ & $-c$ & $-d$ & $-e$ \\
\hline Total ${ }^{14} \mathrm{C}$ & $10.3 \pm 0.9$ & & & \\
\hline
\end{tabular}

${ }^{a}$ If it is assumed that the amount of ${ }^{37} \mathrm{Ar}$ present in the Rio Blanco bottom chimney is the same as that in the top chimney (i.e., the amounts of calcium in the detonation environments are similar), this figure would be about $5000 \pm 500 \mathrm{Ci}$.

${ }^{b}$ If it is assumed that the amount of ${ }^{39} \mathrm{Ar}$ present in the Rio Blanco top chimney is the same as that in the bottom chimney (i.e., the amount of potassium in the detonation environments are similar), this figure would be about $0.5 \pm 0.1 \mathrm{Ci}$.

${ }^{c}$ If it is assumed that the ratio of ${ }^{14} \mathrm{CO}_{2} /{ }^{14} \mathrm{CH}_{4}$ is the same in Rulison as it was in Gasbuggy, then the amount of ${ }^{14} \mathrm{CH}_{4}$ present in the Rulison gas would be $1.1 \pm 0.2 \mathrm{Ci}$, and the total ${ }^{14} \mathrm{C}$ in the gas would be $3.3 \pm 0.3 \mathrm{Ci}$.

${ }^{d}$ With the assumption of footnote $c$, the amount of ${ }^{14} \mathrm{CH}_{4}$ present in the gas would be $0.32 \pm 0.08 \mathrm{Ci}$, and the total ${ }^{14} \mathrm{C}$ in the gas would be $0.93 \pm 0.15 \mathrm{Ci}$.

${ }^{e}$ With the assumption of footnote $c$, the amount of ${ }^{14} \mathrm{CH}_{4}$ present in the gas would be $0.15 \pm 0.04 \mathrm{Ci}$, and the total ${ }^{14} \mathrm{C}$ in the gas would be $0.44 \pm 0.07 \mathrm{Ci}$.

\section{POTENTIAL RADIATION DOSES TO MAN RESULTING FROM WIDESPREAD USE OF NUCLEARLY STIMULATED GAS}

Radiation exposures that could result from the technology of gas well stimulation by nuclear explosions have been considered in some detail in a number of publications. Population doses from the use of nuclearly stimulated gas for household heating as well as for power production have been estimated. Possible exposures to the general public resulting from the use of petrochemical substances employing radioactive natural gas as a feedstock material have also been studied. In addition, the effects of production testing (flaring of nuclearly stimulated gas) have been quantitated. 
Occupational exposures that could be realized in conjunction with gas well stimulation by nuclear explosions have been predicted on the basis of mathematical modeling as well as from some experimental results.

Brief discussions of the approaches used in dose estimation are presented on the following pages.

\section{DOSES TO INDIVIDUAL MEMBERS OF THE PUBLIC}

Average doses to members of the general population that would have resulted if all of the Gasbuggy gas had been introduced into existing pipelines and delivered to California have been calculated. ${ }^{16-19}$ Some of the calculated doses to individuals residing in different California communities are shown in Table 15. Also, average and maximum annual doses to members of the public exposed by the continuous use of gas containing $1 \mathrm{pCi} / \mathrm{cm}^{3}$ of tritium have been estimated for the Los Angeles and San Francisco metropolitan areas $^{17-20}$ and are shown in Table 16. Note that the dose estimates listed in both Tables 15 and 16 include not only the exposures resulting from domestic use of radioactive natural gas (both for heating and cooking), but also the exposures resulting from the use of such gas in steam electric plants in the metropolitan areas.

TABLE 15. ${ }^{\text {a }}$ Potential dose equivalents to various population groups from the hypothetical use of Gasbuggy gas during the lifetime of the well.

\begin{tabular}{lccc}
\hline \multicolumn{1}{c}{ City } & $\begin{array}{c}\text { Heating } \\
\text { requirements } \\
\text { (degree days/yr) }\end{array}$ & $\begin{array}{c}\text { Further dilution } \\
\text { factor } \\
\text { for Blanco gas }\end{array}$ & $\begin{array}{c}\text { Dose equivalents } \\
\text { from tritium } \\
\text { (mrem) }\end{array}$ \\
\hline San Francisco & 2950 & 6.0 & 0.15 \\
Peninsula Cities & 2700 & 6.0 & 0.14 \\
San Jose & 2450 & 6.0 & 0.14 \\
Bakersfield & 2100 & 3.2 & 0.25 \\
Fresno & 2490 & 3.2 & 0.27 \\
Salinas & 2700 & 3.2 & 0.28 \\
Arrowhead Lake & 5400 & 5.3 & 0.23 \\
San Fernando Valley & 1700 & 16 & 0.05 \\
Southeastern & & 5.3 & 0.14 \\
Los Angeles Basin & 1700 & 5 & \\
\hline
\end{tabular}

a From Ref. 19.

${ }^{b}$ Assumes all appliances and heaters nonvented with 1 air change per hour.

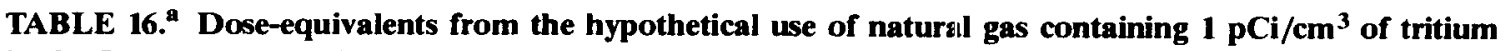
in the Los Angeles Basin and in the San Francisco Bay area.

\begin{tabular}{|c|c|c|}
\hline \multirow[b]{2}{*}{ Source of exposure } & \multicolumn{2}{|c|}{ Dose equivalents (mrem/yr) } \\
\hline & Los Angeles Basin & $\begin{array}{c}\begin{array}{c}\text { San Francisco } \\
\text { Bay area }\end{array} \\
\end{array}$ \\
\hline \multicolumn{3}{|l|}{ Atmosphere } \\
\hline At point of peak concentration & 0.19 & 0.024 \\
\hline Population weighted average & 0.024 & 0.007 \\
\hline \multicolumn{3}{|l|}{ Domestic use (1 air change per hour) } \\
\hline Nonvented heating and appliances & 2.0 & 2.5 \\
\hline All appliances vented except range & 0.27 & 0.27 \\
\hline Weighted average $\mathrm{c}$ & 0.45 & 0.49 \\
\hline \multicolumn{3}{|l|}{ Total } \\
\hline Maximum exposure & 2.2 & 2.5 \\
\hline Weighted average $\mathrm{c}$ & 0.47 & 0.50 \\
\hline
\end{tabular}

\footnotetext{
${ }^{\text {a }}$ From Ref. 19 (Table 6).

${ }^{b}$ Assumes 1700 degree-days of heating for Los Angeles and 2950 for isan Francisco and a 1000-sq-ft residence of normal construction.

c Assumes nonvented heating for $10 \%$ of the population.
} 
Additional calculations were carried out to determine the exposures that would have resulted had Rulison gas been introduced into the distribution system serving a number of small Western Slope communities in Colorado ${ }^{21}$; results are given in Table 17 for the ground level release of Rulison gas combustion products. Note that additional exposure of some members of the public could occur from exposure to combustion products released from unvented appliances; it was estimated that a maximum first-year dose of as much as 18 mrem could occur to a few individuals in Grand Valley.

Calculations indicating the contribution to population dose resulting from combustion of contaminated gas in steam electric plants have been made and reported ${ }^{18}$; the distribution and gas consumption of such generating plants in the Los Angeles basin is shown in Fig. 26. Similar calculations have been made, assuming that gas containing $10 \mathrm{pCi} / \mathrm{ml}$ of tritium was burned in the Cherokee steam electric station in Denver, Colorado ${ }^{22,23}$; the contribution of this source to total population exposures is shown in Table 18.

Some potential population exposure could result from the use of contaminated natural gas in the production of various petrochemicals. This problem has also been considered, and doses have been estimated from a number of different products, assuming that gas containing $1 \mathrm{pCi} / \mathrm{ml}$ of tritium is used as a feedstock. ${ }^{17,18,20,24}$ A summary of the calculated results is given in Table 19.

Liquid hydrocarbons present in natural gas are separated from the gas, either during the flow of the gas through pipelines, or during the course of gas processing. It has been calculated that the maximum dose to members of the public exposed to the combustion products of the liquids from the Gasbuggy experiment (assuming that all of these liquids had been incorporated into gasoline) would be on the order of 0.1 mrem. $^{18,20,25}$

\section{OCCUPATIONAL DOSES}

The primary contributions to occupational exposure will occur at gas processing plants, where contaminated gas components will be flared or used for fuel. It was calculated that, if all of the gas from the Gasbuggy experiment had been run through a processing plant in northwestern New Mexico, most of the occupational dose would result from domestic use of the gas in the homes* of the processing plant em-

\footnotetext{
*Located adjacent to the processing plant
}

ployees (as shown in Table 20). ${ }^{16,17,19,20,25,26,27}$ It should be noted that the estimated occupational exposures are of the same order as the predicted exposures to members of the public, as indicated above.

TABLE 17. ${ }^{\mathrm{a}}$ Yearly doses from ground-level release of Rulison gas combustion products. ${ }^{\text {b }}$

\begin{tabular}{|c|c|c|c|}
\hline \multirow[b]{2}{*}{ Community } & \multicolumn{3}{|c|}{ Calculated doses (mrem/yr) } \\
\hline & 1972 & 1973 & 1974 \\
\hline Aspen & 0.29 & 0.06 & 0.01 \\
\hline Basalt & 0.10 & 0.02 & $<\mathbf{0 . 0 1}$ \\
\hline Carbondale & 0.18 & 0.04 & $<0.01$ \\
\hline Cedaredge & 0.03 & $<0.01$ & $\mathbf{0}$ \\
\hline Collbran & 0 & 0 & $\mathbf{0}$ \\
\hline Delta & 0.09 & $<0.01$ & 0 \\
\hline Eagle & 0.04 & 0.01 & $<0.01$ \\
\hline Eckert & 0.02 & $<0.01$ & $\mathbf{0}$ \\
\hline Glenwood Springs & 0.13 & 0.03 & $<\mathbf{0 . 0 1}$ \\
\hline Gypsum & 0.01 & $<0.01$ & $<\mathbf{0 . 0 1}$ \\
\hline Grand Valley & 0.13 & & \\
\hline Hotchkiss & 0.04 & $<0.01$ & $\mathbf{0}$ \\
\hline Montrose & $\mathbf{0}$ & $\mathbf{0}$ & $\mathbf{0}$ \\
\hline Olathe & $\mathbf{0}$ & 0 & $\mathbf{0}$ \\
\hline Paonia & 0.04 & $<0.01$ & o \\
\hline Rifle & 0.33 & & \\
\hline Snowmass & 0.13 & $\mathbf{0 . 0 3}$ & $<0.01$ \\
\hline
\end{tabular}

TABLE 18. Contributions to total population dose from burning of tritium containing natural gas in Cherokee steam electric plant.

\begin{tabular}{|c|c|c|}
\hline $\begin{array}{c}\text { Source of dose } \\
\text { contribution }\end{array}$ & $\begin{array}{l}\text { Computer } \\
\text { code } \\
\text { used }\end{array}$ & $\begin{array}{c}\text { Contribution } \\
\text { to total } \\
\text { population } \\
\text { dose } \\
\text { (man-rem } / y r) \\
\end{array}$ \\
\hline $\begin{array}{l}\text { Exposures to initial passage } \\
\text { of plumes from plant }\end{array}$ & STACKMANREM & 1.575 \\
\hline $\begin{array}{l}\text { Exposures to plumes from } \\
\text { first wind reversal }\end{array}$ & BLOWBACK 1 & \\
\hline $\begin{array}{l}\text { (1) Plumes blown initially } \\
\text { toward south from } \\
\text { plant }\end{array}$ & & 0.220 \\
\hline $\begin{array}{l}\text { (2) Plumes blown initially } \\
\text { toward north from } \\
\text { plant }\end{array}$ & & 0.025 \\
\hline $\begin{array}{l}\text { Exposures to plumes from } \\
\text { second through tenth } \\
\text { wind reversals }\end{array}$ & BLOWBACK 2 & \\
\hline $\begin{array}{l}\text { (1) Plumes blown initially } \\
\text { toward south from } \\
\text { plant }\end{array}$ & & 0.840 \\
\hline \multirow[t]{2}{*}{$\begin{array}{l}\text { (2) Plumes blown initially } \\
\text { toward north from } \\
\text { plant }\end{array}$} & & 0.310 \\
\hline & & 2.97 \\
\hline
\end{tabular}




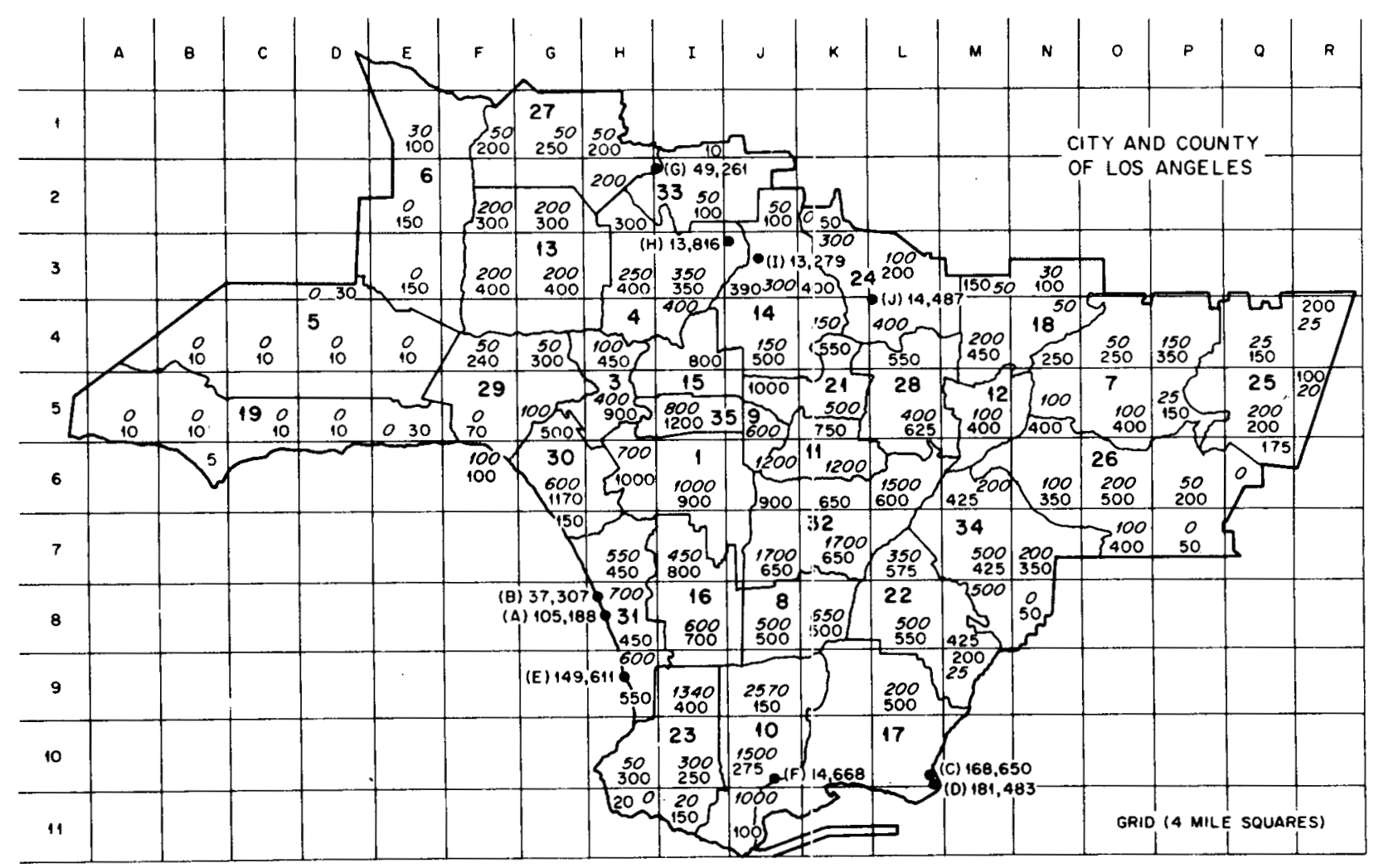

100: RESIDENTIAL $\frac{\text { Mcf }}{\text { day-mile }}$

1000: INDUSTRIAL $\frac{\text { Mcf }}{\text { day-mile }}$

-: STEAM PLANTS $747,550 \frac{\text { Mcf }}{\text { day }}$ (POINT SOURCES)

29: LOS ANGELES COUNTY MAJOR STATISTICAL AREAS
(A) EL SEGUNDO
(B) SCAT TERGOOO
(C) ALAMITOS
(D) HAYNES
(E) REDONDO
(F) HARBOR
(G) VALLEY
(H) BURBANK
(I) GLENDALE
(J) PASADENA

FIG. 26. Gas consumption in Los Angeles Hasin (taken from Ref. 17).

TABLE 19. Summary of estimated doses from ingestion of consurner products manufactured with natural gas containing $1 \mathrm{pCi} / \mathrm{cm}^{3}$ of tritium.

\begin{tabular}{|c|c|c|c|c|}
\hline Product & $\begin{array}{l}\text { Daily consumption } \\
\text { of product }(\mathrm{g})\end{array}$ & $\begin{array}{l}\text { Tritium concentration } \\
\text { in product }(\mathrm{pCi} / \mathrm{g})\end{array}$ & $\begin{array}{l}\text { Daily tritium } \\
\text { intake (pCi) }\end{array}$ & $\begin{array}{l}\text { Estimated annual } \\
\text { dose (mrem) }\end{array}$ \\
\hline Ethanol & 64.5 & $1.08 \times 10^{3}$ & $4.2 \times 10^{4}$ & 0.9 \\
\hline $\begin{array}{l}\text { Grain-NH3 } \\
\text { fertilizer }\end{array}$ & 454 & 0.0068 & $\mathbf{3}$ & 0.0001 \\
\hline $\begin{array}{l}\text { Hydrogenated } \\
\text { oleic acid }\end{array}$ & 454 & 40 & $1.8 \times 10^{4}$ & 0.4 \\
\hline Aspirin & 2.6 & 90 & 240 & 0.005 \\
\hline $\begin{array}{l}\text { Synthetic } \\
\text { protein }\end{array}$ & 18 & 390 & $7.2 \times 10^{3}$ & 1.0 \\
\hline $\begin{array}{l}\text { Modified } \\
\text { starch }\end{array}$ & 2 & 120 & 240 & 0.016 \\
\hline Sorbitol & 7 & 41 & 290 & 0.007 \\
\hline
\end{tabular}


TABLE 20. ${ }^{\text {a }}$ Potential contribution to radiation dose to residents of Blanco camp from hypothetical processing of all of gas produced from Gasbuggy well during its lifetime.

\begin{tabular}{lccc}
\hline & \multicolumn{3}{c}{ Dose equivalents (mrem) } \\
\cline { 2 - 4 } & Tritium & Krypton-85 & Carbon-14 \\
\hline Flare pit & 0.03 & 0.005 & $<0.001$ \\
Boiler fuel & 0.07 & 0.010 & $<0.001$ \\
Compressor fuel & 0.05 & 0.007 & $<0.001$ \\
Domestic use & 1.3 & 0.24 & 0.003 \\
$\quad$ Totals & 1.4 & 0.26 & 0.003 \\
\hline
\end{tabular}

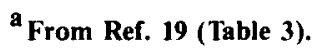

${ }^{b}$ Dose-equivalents calculated for tritium and ${ }^{14} \mathrm{C}$ are those to gonads; those for ${ }^{85} \mathrm{Kr}$ are for skin surface.

${ }^{c}$ Assumes all appliances and heaters nonvented with 1 air change per hour.

\section{POPULATION DOSES FROM FULL-FIELD DEVELOPMENT}

In order to limit the maximum dose that could be delivered to members of the public, it would be necessary to control the concentration of radioactivity present in the natural gas being used for residential heating and electric power production. This control could involve the careful planning of well stimulation and production schedules, so that gas from newly stimulated wells could be diluted with low specific activity gas from older wells. A computer program for production scheduling has been formulated ${ }^{28}$; results from this program indicate that concentrations of tritium in gas delivered to residential users can be kept at or below the levels assumed in the calculations discussed above.

A study has been made of the radiological consequences of using nuclearly stimulated gas to supply the energy needs of California, assuming the radionuclide concentrations in gas shown in Table $21 .{ }^{29}$ Note that these concentrations of radioactivity appear to be consistent with those observed in the gas from the Rio Blanco experiment. On the basis of the assumptions of the study, annual population doses in California would be as shown in Table 22. If the gas is placed in general use, population exposure will be only about $1 / 250$ th of that received from natural background.

It is possible that, in the course of gas field development, production testing (gas flaring) might be desirable to estimate resource characteristics. ${ }^{31}$ Table 23 shows the population dose that could result from each well tested; the number is very small as compared with those given in Table 22 for domestic use of nuclearly stimulated gas in California.

In summary, the principal contribution to total population dose from the utilization of nuclearly stimulated gas resources comes from the use of contaminated gas for home heating and cooking. Contributions from occupational exposure, production testing (flaring), use of gas for steam electrical generation, use of gas as petrochemical feedstock, etc., all appear to be relatively insignificant. As noted earlier, even extensive use of nuclearly stimulated gas would result in only a small incremental increase in population dose above that which is due to natural background radiation.

\section{REGULATORY ISSUES IN THE USE OF NUCLEARLY STIMULATED NATURAL GAS}

Currently, there are a number of products containing radioactivity that have been granted an exemption from licensing by the Nuclear Regulatory Commission (NRC). Among these are such items as luminous signs or indicators for use in aircraft (containing tritium), and cardiac pacemakers, which are powered by ${ }^{238} \mathrm{Pu}$. Presumably, the procedures for including nuclearly stimulated natural gas in this list of exempt materials would be the same as those followed by the NRC in past cases.

The first requirement is that a commercially soluable material has been produced and is available for distribution; i.e., the NRC must be presented with a tangible need for action. Typically, no action would be taken on the basis of a proposed course of action alone. The vendor then petitions the NRC to engage in rulemaking in order that appropriate guidelines can be promulgated under which radioactive gas can be distributed to the general public without subjecting the consumers to an unreasonably high radiation exposure. The rulemaking procedure typically requires about two years, and a generic environmental impact statement (EIS) would be needed. Presumably, the applicant would have to furnish a large fraction of the information needed to prepare the EIS, and the statement would have to contain a cost-benefit analysis in which one of the costs is the effect on the general public of the radioactivity contained in the nuclearly stimulated gas.

Once the rulemaking activity has been concluded, the applicant must file for an exemption from licensing, which will allow the applicant to sell his product 
TABLE 21. Average radionuclide concentrations in produced gas (after carbon dioxide and water removal). ${ }^{29}$

\begin{tabular}{|c|c|c|c|c|}
\hline \multirow[b]{2}{*}{ Basin } & \multirow{2}{*}{$\begin{array}{c}\text { No. of 100-kt } \\
\text { explosives } \\
\text { per well }\end{array}$} & \multirow[b]{2}{*}{ Year } & \multicolumn{2}{|c|}{ Annual average concentration $\left(\mathrm{pCi} / \mathrm{cm}^{3}\right)$} \\
\hline & & & Tritium $^{\mathrm{a}}$ & Krypton-85 \\
\hline \multirow[t]{2}{*}{ Green River } & 4 & 1 & $11^{\mathrm{b}}$ & 71 \\
\hline & & 2 & $0.015^{b}$ & 0.1 \\
\hline \multirow[t]{2}{*}{ Piceance } & 3 & 1 & $<8^{c}$ & 60 \\
\hline & & 2 & $<0.004^{\mathrm{c}}$ & 0.02 \\
\hline
\end{tabular}

${ }^{a}$ Assumes negligible exchange of tritium from water to methane after the start of production.

brom Ref. 30.

${ }^{c}$ Based on a $<2000-C i$ tritium residual for a 100-kt Diamond explosive in a gas well environment.

TABLE 22. Population dose delivered to California residents from various sources. ${ }^{29}$

\begin{tabular}{|c|c|c|c|c|c|}
\hline \multirow[b]{2}{*}{ Source } & \multirow{2}{*}{$\begin{array}{c}1970 \\
\text { estimated } \\
\text { individual } \\
\text { exposure } \\
(\mathrm{mrem} / \mathrm{yr} \text { av) }\end{array}$} & \multirow{2}{*}{$\begin{array}{c}1970 \\
\text { estimated } \\
\text { population } \\
\text { exposure } \\
\text { (man-rem/yr) }\end{array}$} & \multicolumn{2}{|c|}{$\begin{array}{c}2000 \\
\text { estimated } \\
\text { individual } \\
\text { exposure } \\
\text { (mrem/yr) } \\
\end{array}$} & \multirow{2}{*}{$\begin{array}{c}2000 \\
\text { estimated } \\
\text { population } \\
\text { exposure } \\
\text { (man-rem/yr) }\end{array}$} \\
\hline & & & Av & Max & \\
\hline Natural background & 114 & $2,300,000$ & 114 & - & $3,500,000$ \\
\hline All medical sources & 98 & $2,000,000$ & 160 & - & $5,200,000$ \\
\hline Nuclear atmospheric tests & 5 & 100,000 & 5 & - & 160,000 \\
\hline $\begin{array}{l}\text { Nuclear power reactors } \\
\text { Power-reactor fuel }\end{array}$ & 0.002 & 40 & $\sim 0.2$ & - & 6,000 \\
\hline reprocessing & 0.0008 & 16 & 0.2 & - & 6,000 \\
\hline \multicolumn{6}{|l|}{ Gas Stimulation } \\
\hline $\begin{array}{l}\text { General use of all gas } \\
\text { Power plant use of }\end{array}$ & - & - & $<0.45$ & $<0.7$ & $<14,000$ \\
\hline
\end{tabular}

TABLE 23. Estimated individual and population exposures from Rio Blanco gas flaring.

\begin{tabular}{|c|c|c|c|c|}
\hline \multirow[b]{2}{*}{ Nuclide } & \multicolumn{4}{|c|}{ Doses $^{a}$} \\
\hline & $\begin{array}{c}\text { Submersion } \\
\text { (nrem) }\end{array}$ & $\begin{array}{c}\text { Inhalation } \\
\text { skin absorption } \\
\text { (nrem) }\end{array}$ & $\begin{array}{c}\text { Forage } \\
\text { cow milk } \\
\text { (nrem) }\end{array}$ & $\begin{array}{c}\text { Pasture meat } \\
\text { (nrem) }\end{array}$ \\
\hline $\mathrm{H}-3$ (as HTO) & 1.8 & 37 & 140 & 9.7 \\
\hline Ar-37 & 7.0 & - & - & - \\
\hline Kr-85 & 110 & - & - & - \\
\hline
\end{tabular}

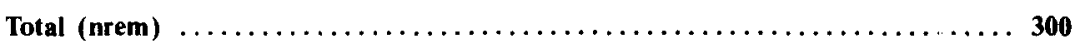

Total man-rem $\ldots \ldots \ldots \ldots \ldots \ldots \ldots \ldots \ldots \ldots \ldots \ldots \ldots \ldots \ldots \ldots \ldots \ldots \ldots, 0.2^{\mathrm{c}}$

${ }^{a}$ Plume centerline doses calculated for $50 \mathrm{~km}$ downwind.

${ }^{\text {b } 37} \mathrm{Ar}$ doses are calculated, allowing for the radioactive decay of the nuclide.

${ }^{c}$ Population exposure out to $1000 \mathrm{~km}$, based on plume width at distanice 'd' from the plume source being equal to 'd', and a population density of 13 per $\mathrm{km}^{2}$, (appropriate for the Rocky Mountain States). 
to customers who do not have a license permitting them to use radioactive material. In granting this exemption it is quite possible that the NRC will have to generate another, project-specific, EIS to supplement the already-issued generic statement. It is estimated that this phase of the proceedings could require between one and two years to complete. Thus, the first applicant desiring to market nuclearly stimulated gas must be prepared to spend between three or four years after the gas has been produced and is ready for distribution to satisfy the regulatory requirements.

It should be noted at this time that there is a possibility that the Environmental Protection Agency (EPA) could become involved in the regulatory process, much as they did in the case of the nuclear fuel cycle; i.e., a maximum annual population dose could be established for nuclearly stimulated gas, similar to that promulgated for the nuclear fuel cycle. ${ }^{32}$
A tentative standard has been informally proposed for nuclearly stimulated gas ${ }^{33}: 1 \mathrm{pCi} / \mathrm{ml}$ (STP) of tritium in natural gas, which under the conditions used in Ref. 33 would result in a body burden of about $0.65 \mu \mathrm{Ci}$. This body burden would result in an annual whole body dose of about 5 mrem. While it appears that this standard could be met with current technology, it should be emphasized that there has been no effort to propose formally that this standard be used for nuclearly stimulated gas.

Although at one time, a gas distribution company expressed interest in the marketing of Rulison gas, the complex and time-consuming regulatory requirements that had to be fulfilled discouraged the potential applicant from pursuing the matter beyond the stage of preliminary inquiries.

\section{ACKNOWLEDGMENT}

All of the data and many of the data analyses presented in this report were taken from work done by Charles F. Smith, Jr. of this laboratory, as shown in Refs. 1 through 4 . I have rearranged the data into a single format, and have subjected the data from Gasbuggy and Rio Blanco (Refs. 1, 3, and 4) to the analytical treatment described in Ref. 2 to facilitate intercomparison of the experimental results.

I wish also to express my appreciation to Dr. Smith for his careful reading of the original manuscript of this report, and for his helpful comments and suggestions. 


\section{REFERENCES}

1. C. F. Smith, Jr., Project Gasbuggy: Gas Quality Analysis and Evaluation Program: Tabulation of Radiochemical Analytical Results, Lawrence Livermore Laboratory, Livermore, Calif, UCRL-50635, Rev. 2. (1971).

2. C. F. Smith, Jr., Gas Analysis Results for Project Rulison Production Testing Samples, Lawrence Livermore Laboratory, Livermore, Calif., UCRL-51153 (1971).

3. C. F. Smith, Jr., Rio Blanco Gas Composition LLL Data Summary: Calibration and Production Testing of $R B-E-01$, Lawrence Livermore Laboratory, Livermore, Calif, UCID-16579 (1974).

4. C. F. Smith, Jr., Rio Blanco Gas Composition LLL Data Simmary: Calibration and Production Testing of RB-AR-02, Lawrence Livermore Laboratory, Livermore Calif, UCID-16762 (1975).

5. R. W. Taylor, E. L. Lee, and J. H. Hill, "Interpreting the Chemical Results of the Gasbuggy Experiment," in Proc. Symp. Engrg. Nucl. Explosives, Las Vegas, Nevada, January 14-16, 1970, AEC Rept. CONF-700101 (1970), pp. 794-814.

6. A. Holzer, "Gasbuggy in Perspective," in Proc. Symp. Engrg. Nucl. Explosives, Las Vegas, Nevada, January 14-16, 1970, AEC Rept. CONF-700101 (1970), pp. 662-697.

7. R. E. Bozak and R. W. Taylor, The Effects of Heat and Radiation in Gasbuggy Chimney Gas, Lawrence Livermore Laboratory, Livermore, Calif., UCRL-51293 (1972).

8. M. Reynolds, Jr., "Project Rulison--Summary of Results and Analyses," Nucl. Technol. 14, 187-193 (1972).

9. J. Toman, "Production Test Data and Preliminary Analysis of Top Chimney/Cavity," Nucl. Technol. 27, $692-704$ (1975).

10. F. Holzer, Gasbuggy Preshot Summary Report, Lawrence Livermore Laboratory, Livermore, Calif., UCRL-50345 (1967).

11. F. Holzer, Gasbuggy Preliminary Postshot Summary Report, Lawrence Livermore Laboratory, Livermore, Calif., UCRL-50386 (1968).

12. C. F. Smith, Jr., Nongaseous Radioisotopes-- Project Gasbuggy Chimney Gas, Lawrence Livermore Laboratory, Livermore, Calif., UCRL-50634 (1968).

13. R. W. Taylor, Thermal Effects of Underground Nuclear Ixpplosions, Lawrence Livermore Laboratory, Livermore, Calif., UCRL-74052 (1972).

14. G. R. Luetkehans, J. Toman, and B. G. Dibona, "The Rio Blanco Experiment - Its Objectives, Design, and Execution," Nucl. Technol. 27, 539-558 (1975).

15. C. F. Smith, Jr., "Behavior of Radionuclides in Nuclear Gas Stimulation Applications," in Proc. Symp. Engrg. Nucl. Explosives, Las Vegas, Nevada, January 14-16, 1970, AEC Rept. CONF-700101 (1970), pp. 818-830.

16. D. G. Jacobs, E. G. Struxness, and C. R. Bowman, "A Preliminary Assessment of the Radiological Implications of Commercial Utilization of Natural Gas from a Nuclearly Stimulated Well," in Proc. Symp. Engrg. Nucl. Explosives, Las Vegas, Nevada, January 14-16, 1970, AEC Rept. CONF-700101 (1970), pp. 831-849.

17. C. J. Barton, D. G. Jacobs, M. J. Kelly, and E. G. Struxness, "Radiological Considerations in the Use of Natural Gas from Nuclearly Stimulated Wells," Nucl. Technol. 11, 335-344 (1971).

18. D. G. Jacobs et al., Theoretical Evaluation of Consumer Products from Project Gasbuggy-- Final Report. Phase II: Hypothetical Population Exposures Outside San Juan Basin, Oak Ridge National Laboratory, Tenn., ORNL-4748 (1972).

19. D. G. Jacobs, E. G. Struxness, M. J. Kelly, and C. R. Bowman, "Consideration of the Radiological Impact from the Hypothetical Use of Contaminated Natural Gas from Nuclearly Stimulated Reservoirs," Health Phys. 22, 429-440 (1972).

20. D. G. Jacobs and E. G. Struxness, "Radiological Safety Considerations in the Distribution of Natural Gas that Contains Radionuclides," in Peaceful Nuclear Explosions II: Proceedings of a Panel, Vienna, 18-22 January 1971, International Atomic Energy Rept. STI/PUB/298 (1971), pp. 319-339.

21. C. J. Barton, R. E. Moore, and S. R. Hanna, "Radiation Doses from Hypothetical Exposures to Rulison Gas," Nucl. Technol. 20, 35-50, (1973). 
22. R. E. Moore and C. J. Barton, "Dose Estimations for the Hypothetical Use of Nuclearly Stimulated Natural Gas in the Cherokee Steam Electric Station, Denver, Colorado," Oak Ridge National Laboratory, Tenn. ORNL-TM-4026 (1973).

23. R. E. Moore and C. J. Barton, "Radiation Doses from Hypothetical Exposures to Combustion Products of Plowshare Gas Discharged from Stacks," Nucl. Technol. 24, 238-245 (1974).

24. C. J. Barton and S. A. Reynolds, Estimated Radiation Doses from Ingestion of Tritium--Containing Consumer Products Made with Hydrocarbons from Nuclearly. Stimulated Natural Gas Wells, Oak Ridge National Laboratory, Tenn., ORNL-TM-4730 (1974).

25. M. J. Kelly et al., Theoretical Evaluation of Consumer Products from Project Gasbuggy. Final Report. Tritium Behavior in a Natural Gas Processing Plant, Oak Ridge National Laboratory, Tenn., ORNL-4775 (1972).

26. D. G. Jacobs et al., Theoretical Evaluation of Consumer. Products from Project Gasbuggv, Final Report, Phase V: Impact of Hypothetical Releases of Contaminated Gas in the San Juan Basin, Oak Ridge National Laboratory, Tenn., ORNL-4646 (1971).

27. M. J. Kelly et al., "Experimental Results from Processing Gasbuggy Gas in a Natural Gas Processing Plant," in Tritium (A. A. Moghissi and M. W. Carter, Eds.), Messenger Graphics, Phoenix, Ariz., and Las Vegas, Nev. (1973), CONF-710809, pp. 603-611.

28. R. E. Moore and E. J. Barton, Progress Report on Radiological Safety of Peaceful Uses of Nuclear Explosives: Preliminary Equations and Computer Techniques for Estimating and Controlling Tritium Doses from Nuclearly Stimulated Natural Gas, Oak Ridge National Laboratory, Tenn., ORNL-TM-3755 (1972).

29. B. Rubin, L. Schwartz, and D. Montan, An Analysis of Gas Stimulation Using Nuclear Explosives, Lawrence Livermore Laboratory, Livermore, Calif., UCRL-51226 (1972).

30. G. Werth et al., An Analysis of Nuclear-Explosive Gas Stimulation and the Program Required for Its Development, Lawrence Livermore Laboratory, Livermore, Calif,, UCRL-50966 (1971).

31. H. A. Tewes and L. L. Schwartz, "Potential Pathways to Man for Radionuclides from Contained Applications of Peaceful Nuclear Explosives," in Peaceful Nuclear Explosions IV: Proceedings of a Technical Committee, Vienna, 20-24, January 1975, International Atomic Energy Agency Rept. STI/PUB/414 (1975), pp. 297-320.

32. Code of Federal Regulations, Title 40, Chapter 1, Part 190, Subpart B, Section 190.10.

33. A. A. Moghissi, R. G. Patzer, D. N. McNelis, and M. W. Carter, "Background Information for the Development of a Radiation Standard for Tritium in Nuclear Stimulated Natural Gas," in Radiation Protection Standards: Quo Vadis. Proceedings of the Sixth Annual Health Physic Society Topical Symposium, Richland, Wash. (1971), pp. 228-235. 